\title{
EPIDEMIOLOGY OF NEGLECTED TROPICAL DISEASES IN TRANSPLANT RECIPIENTS. REVIEW OF THE LITERATURE AND EXPERIENCE OF A BRAZILIAN HSCT CENTER
}

Clarisse Martins MACHADO(1,2), Talita Chaves MARTINS(1), Iago COLTURATO(2), Marília Souza LEITE(1), Anderson João SIMIONE(1), Mair Pedro de SOUZA(1), Marcos Augusto MAUAD(1) \& Vergílio Rensi COLTURATO(1)

\begin{abstract}
SUMMARY
The rising success rate of solid organ (SOT) and haematopoietic stem cell transplantation (HSCT) and modern immunosuppression make transplants the first therapeutic option for many diseases affecting a considerable number of people worldwide. Consequently, developing countries have also grown their transplant programs and have started to face the impact of neglected tropical diseases (NTDs) in transplant recipients. We reviewed the literature data on the epidemiology of NTDs with greatest disease burden, which have affected transplant recipients in developing countries or may represent a threat to transplant recipients living in other regions. Tuberculosis, Leprosy, Chagas disease, Malaria, Leishmaniasis, Dengue, Yellow fever and Measles are the topics included in this review. In addition, we retrospectively revised the experience concerning the management of NTDs at the HSCT program of Amaral Carvalho Foundation, a public transplant program of the state of São Paulo, Brazil.
\end{abstract}

KEYWORDS: Neglected tropical diseases; Transplantation; Developing countries; HSCT; Epidemiology.

\section{INTRODUCTION}

Tropical developing countries have experienced prolonged periods of economy decline and poverty. Along with the economic challenges, these countries are characterized by the occurrence of endemic infections and diseases that are absent or rare in developed countries, and have been categorized as "neglected tropical diseases" (NTD) by the World Health Organization (WHO).

They are named "neglected" because persist exclusively in marginalized and poor communities, and were forgotten in wealthier places as they have been largely eliminated in developed countries. About one billion people are affected by one or more neglected tropical diseases which cause approximately 534,000 deaths annually ${ }^{48,110}$.

According to the WHO, the neglected tropical diseases include soiltransmitted helminth infections (ascaridiasis, trichuriasis, hookworm infection, etc), filariasis, onchocerciasis, dracunculiasis, schistosomiasis, Chagas' disease, African trypanosomiasis, leishmaniasis, Buruli ulcer, leprosy, trachoma, dengue fever, the treponematoses, leptospirosis, strongyloidiasis, food-borne trematodiases, as well as other tropical infections.

The rising success rate of solid organ (SOT) and haematopoietic stem cell transplantation (HSCT) and modern immunosuppression make transplants the first therapeutic option for many diseases affecting a considerable number of people worldwide. Thus, populous developing countries have faced a growing need of transplant procedures and struggled to develop public financing programs for SOT and HSCT to assure universal accessibility and avoid any kind of commerce.

Some developing countries such as Argentina, Brazil, China, India, Mexico, South Africa and South Korea are considered emerging or developing economies since they have shown a sustained economic growth. As a consequence of more investments in tertiary healthcare policies, transplant programs have grown in these countries. In 2004, among the five countries performing the greatest number of renal transplant procedures in the world, three were developing countries: USA performed 15,993 renal transplants, followed by China with 5,501 transplants, India with 3,406, Brazil with 3,234 and France with 2,423 transplants ${ }^{71}$.

Table 1 shows the most prevalent tropical infectious diseases in developing countries. Although highly prevalent in general population in these countries, some of them have not been described in transplant recipients or do not have an increased risk in this population.

We reviewed the literature data on the epidemiology of NTDs with greatest disease burden, which have affected transplant recipients in developing countries or may represent a threat to transplant recipients living in other regions. Tuberculosis, Leprosy, Chagas disease, Malaria,

Work published as part of the celebration of the $50^{\text {th }}$ anniversary of the São Paulo Institute of Tropical Medicine (1959/2009).

(1) HSCT Program - Fundação Hospital Amaral Carvalho, Jaú, SP, Brazil.

(2)Virology Laboratory, Institute of Tropical Medicine, University of São Paulo, São Paulo, SP, Brazil.

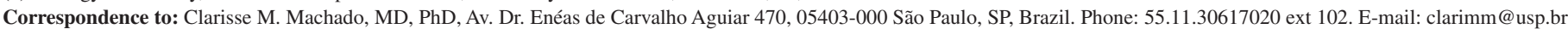


MACHADO, C.M.; MARTINS, T.C.; COLTURATO, I.; LEITE, M.S.; SIMIONE, A.J.; SOUZA, M.P.; MAUAD, M.A. \& COLTURATO, V.R. - Epidemiology of neglected tropical diseases in transplant recipients. Review of the literature and experience of a Brazilian HSCT center. Rev. Inst. Med. trop. S. Paulo, 51(6): 309-324, 2009.

Table 1

Distribution of tropical and neglected diseases according to region*

\begin{tabular}{|c|c|c|c|}
\hline Region & Viruses & Bacteria & Parasites \\
\hline North Africa & Hepatitis A, rabies & $\begin{array}{l}\text { Plague, tuberculosis, typhoid and } \\
\text { paratyphoid fever }\end{array}$ & Leishmaniasis \\
\hline Sub-Saharan Africa & $\begin{array}{l}\text { Dengue, rabies, hepatitis A, hepatitis } \\
\text { B, yellow fever, poliomyelitis, other } \\
\text { viral hemorrhagic fevers }\end{array}$ & $\begin{array}{l}\text { Diphtheria, tuberculosis, plague, } \\
\text { leprosy }\end{array}$ & $\begin{array}{l}\text { Leishmaniasis, malaria, } \\
\text { schistosomiasis, trypanosomiasis }\end{array}$ \\
\hline $\begin{array}{l}\text { Mexico, Central } \\
\text { America }\end{array}$ & Dengue, hepatitis A & $\begin{array}{l}\text { Leptospirosis, typhoid and } \\
\text { paratyphoid fever }\end{array}$ & Leishmaniasis \\
\hline Latin America & $\begin{array}{l}\text { Dengue, yellow fever, rabies, hepatitis } \\
\text { A, hepatitis B, measles, hantavirus, } \\
\text { other viral hemorrhagic fevers }\end{array}$ & $\begin{array}{l}\text { Tuberculosis, leprosy, leptospirosis, } \\
\text { plague }\end{array}$ & $\begin{array}{l}\text { Leishmaniasis, malaria, } \\
\text { schistosomiasis, trypanosomiasis }\end{array}$ \\
\hline Southeast Asia & Dengue, hepatitis A, hepatitis B & Leptospirosis, plague, Tuberculosis, & Filariasis, malaria, schistosomiasis \\
\hline South Asia & $\begin{array}{l}\text { Filariasis, hepatitis A, hepatitis B, } \\
\text { rabies }\end{array}$ & Leptospirosis, plague, Tuberculosis, & Filariasis, leishmaniasis, malaria \\
\hline East Asia & Hantavirus, hepatitis A, hepatitis B & Leptospirosis, plague, Tuberculosis, & \\
\hline Northern Asia & $\begin{array}{l}\text { Hantavirus, hepatitis A, hepatitis B, } \\
\text { rabies }\end{array}$ & Diphtheria, tuberculosis & \\
\hline Middle East & Hepatitis A, hepatitis B & Tuberculosis, & Leishmaniasis \\
\hline
\end{tabular}

(*) include only diseases with widespread transmission, epidemic activity or high risk for infection in some areas.

Leishmaniasis, Dengue, Yellow fever and Measles are the topics included in this review. In addition, we retrospectively revised the experience concerning to the management of NTDs at the HSCT program of Amaral Carvalho Foundation, a public transplant program of the state of São Paulo, Brazil.

\section{LITERATURE REVIEW}

\section{Tuberculosis}

According to the WHO, the number of new cases of all forms of tuberculosis (TB) increased from more than 6.5 millions in 1990 to 9.2 millions in 2006. India, China, Indonesia, South Africa and Nigeria have the greatest incidence rates. Asia (South-East Asia and Western Pacific regions) and Africa account for 55\% and $31 \%$ of global cases of TB. HIV pandemic has contributed to these numbers. Since the rate of cure in new cases of smear-positive TB is lower among HIV-positive patients $(<$ $40 \%$ ) in comparison to HIV-negative (>60\%), transmission is facilitated in places where HIV infection is highly prevalent ${ }^{111}$.

One of the components of the WHO program for TB elimination is the recognition and treatment of latent tuberculosis infection (LTBI). Persons at high risk for TB are those who were either infected recently or have clinical conditions that are associated with progression from LTBI to active TB. In this latter group are included HIV infection, transplantation, Diabetes mellitus, gastrectomy, chronic renal failure, among others. Among transplant patients, renal and cardiac transplant recipients have the highest risk ${ }^{91}$.

Almost all developing countries with active transplant programs, such as Argentina, Brazil, China, Egypt, India, Iran, Nigeria, Pakistan, South
Africa, Taiwan, Thailand, Turkey, among others, have reported TB cases in transplant recipients, nicely reviewed in some publications ${ }^{3,79,95}$. The majority of the reports are in solid organ transplant recipients, especially after renal transplantation.

1.1. Transmission in transplant recipients: Tuberculosis among transplant recipients may arise from reactivation of quiescent foci of M. tuberculosis, transmission by the graft or contamination by actively infected persons ${ }^{95}$. Graft transmission has been documented in renal, lung and hepatic transplantation, but accounts for less than $5 \%$ of all TB cases in transplant recipients ${ }^{95}$. Cross-transmission of TB has led to an outbreak in a renal transplant unit but also appears to be a rare event ${ }^{97}$. Reactivation of LTBI accounts for the vast majority of TB cases reported in transplant recipients, and largely reflects the local incidence. In North America, the prevalence of LTBI among renal transplant recipients is $0.5 \%$ to $1 \%$, in Northern Europe is $1 \%$ to $4 \%$, and can reach $15 \%$ in India and Pakistan ${ }^{57,90}$.

The risk of TB in transplant recipients is estimated to be 20 to 50 times higher than in general population even in developed countries ${ }^{3,79}$, and mortality rates vary from 20 to $40 \%{ }^{95}$. Risk factors include pulmonary images suggesting previous TB infection, immunosuppressive treatment with OKT3 or anti-T cell antibodies, Diabetes mellitus, chronic liver disease and coexisting infections ${ }^{3,51,79,95}$. Tuberculosis is rare after HSCT and ten times less frequent than in SOT, as HSCT recipients do not receive lifelong immunosuppression. The main risk factor is undergoing transplant in a country with a high endemic rate of $\mathrm{TB}^{17}$. Unrelated or mismatched related transplants, graft versus host disease (GVHD) and total body irradiation increase the risk of TB reactivation after $\mathrm{HSCT}^{27}$. Thus, investigation of epidemiological risk for LTBI is mandatory in transplant recipients. 


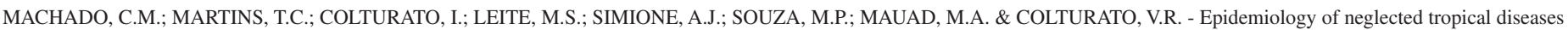
in transplant recipients. Review of the literature and experience of a Brazilian HSCT center. Rev. Inst. Med. trop. S. Paulo, 51(6): 309-324, 2009.

LTBI can also be evaluated through the tuberculin skin test (TST). The sensitivity of the TST is lower in immunocompromised hosts and induration $\geq 5 \mathrm{~mm}$ is considered positive ${ }^{99}$. In solid organ transplantation, around $20 \%$ of the recipients test positive, being the positivity greater in liver transplant recipients (around 70\%) ${ }^{95}$. Positivity of $23 \%$ was observed among HSCT recipients ${ }^{100}$. It is important to highlight that the specificity of TST may be impaired in transplant patients from developing countries since a positive test may indicate infection with non-tuberculous mycobacteria or previous vaccination with the Bacille Calmette-Guérin (BCG $)^{81}$. The role of TST as well as the new interferon-gamma release assays (IGRAs), such as the QuantiFERON test, in the evaluation of LTBI in transplant recipients has not been fully investigated and prospective studies are lacking. A recent meta-analysis suggests that IGRAs may be more sensitive than TST in immunocompromised patients suspected of having $\mathrm{TB}^{73}$.

1.2. Recommendations: Pre-transplant evaluation of epidemiological risk of TB should be made for donors and recipients. Previous TB infection or contact with infected persons should be particularly investigated as well as careful radiological evaluation to check for images suggestive of previous healed TB.

- $\quad$ TST with five tuberculin units of purified protein derivative should be administered to transplant candidates and a negative test should not exclude the possibility of LTBI.

- If LTBI is suspect, treatment with isoniazid (INH) should be started. A full 9-month course is recommended. Alternative schedules may be considered in individual basis. In HSCT recipients, the combination of pyrazinamide and rifampin has known significant liver toxicity and its use is not recommended ${ }^{102}$.

\section{Leprosy}

Leprosy is a chronic infectious disease caused by Mycobacterium leprae, an acid-fast rod-shaped bacillus discovered by G.A. Hansen in 1873. Humans are the principal reservoir of M. leprae and the disease spreads by aerosolized droplets from multibacillary patients, and less commonly through direct skin contact ${ }^{15}$. Recent studies have suggested that direct contact with wild armadillos may contribute to the transmission of leprosy in some areas ${ }^{26,32}$.

The onset of leprosy can be insidious and the disease may be difficult to recognize. In a susceptible host, a skin lesion may develop after an incubation period averaging two to four years, varying from three months to 40 years ${ }^{15}$. This initial phase is called intermediate leprosy and in many patients the lesions can heal spontaneously or progress to a clinical spectrum depending on the host immune response to M. leprae.

According to the type of $\mathrm{T}$ cell response, the granulomatous spectrum of leprosy is classified in tuberculoid (TT), characterized by few skin lesions and low bacterial loads, borderline tuberculoid (BT), borderline (BB), borderline lepromatous (BL) and lepromatous (LL), characterized by diffuse skin lesions and high bacterial loads ${ }^{15}$. A predominant T-helper 1 (Th1) response to $M$. leprae is encountered in lesions of patients with TT and BT forms, in contrast to the Th2 profile found in disseminated lesions of patients with BB, BL, and LL forms of leprosy. Classifying leprosy is important to ensure appropriate treatment particularly for the multibacillary form of the disease ${ }^{16}$.
2.1. Geographic distribution: The vast majority of the world's population is not susceptible to leprosy. Susceptibility appears to be determined by genetic characteristics ${ }^{1}$. Since the introduction by the WHO Leprosy Elimination Program of multidrug therapy (MDT) free of charge to all patients worldwide, most previously highly endemic countries have reached leprosy elimination (registered prevalence rate $<1$ case per 10000 population $)^{65}$. However, some areas in Brazil, Angola, Central African Republic, Democratic Republic of Congo, India, Madagascar, Mozambique, Nepal and Tanzania remain with high endemicity.

2.2. Leprosy in transplant recipients: In SOT recipients, 21 cases of leprosy have been described, three in heart transplant recipients ${ }^{43,58,76}$ and 18 in renal transplant recipients, recently reviewed by GASINK et al. ${ }^{43}$. All cases occurred in patients who were living or had lived in leprosy endemic areas. The majority of the cases was exposed to M. leprae many years before transplantation and developed leprosy five months to 12 years after transplantation. Two patients had active lesions at the time of transplant. Immunosuppression apparently did not adversely affect the treatment of leprosy in most patients though alternative drug schedule were used because of fear of adverse effects ${ }^{30,43}$.

In the scenario of HSCT, six cases of leprosy were reported in a recent publication from Brazil, all in allogeneic HSCT recipients ${ }^{83}$. Three of the six patients had leprosy before transplantation and the disease reappeared after transplant, two cases as BL and one as TT leprosy. In the other three cases, leprosy was diagnosed after HSCT (median 222 days). None of these patients had a previous history of leprosy or contact with persons with the disease, and the source of M. leprae was unknown. The clinical forms seen in these cases were LL, BL and BT. Two patients (LL and BL) had a good response to the treatment, and in the remaining one (BT), the skin lesions had not healed after eight months of clofazimine. Similarly to the SOT leprosy cases, alternative drug schedules were used in the HSCT recipients to avoid possible adverse events ${ }^{83}$. Thus, information about the safety, efficacy and possible drug interactions of classical MDT schedule in transplant recipients could not be obtained from the available data.

\section{Chagas disease}

Chagas disease is caused by Trypanosoma cruzi, a protozoan parasite generally transmitted by feces of infected triatomine insects through penetration of the parasite into the bite wound, conjunctiva or other mucous membrane ${ }^{11}$. Transmission can also occur from mother to child, by organ transplantation, blood transfusion, laboratory incident, and more recently, some outbreaks due to the ingestion of contaminated food or drink have been reported ${ }^{13,22,35,41,93}$.

3.1. Geographic distribution: Chagas disease is endemic from the south of the United States to the south of Latin America. In endemic areas, $T$ cruzi infection is usually acquired in childhood ${ }^{13}$.

In 1991, the Southern Cone Initiative against Chagas disease proposed the interruption of transmission by the elimination of domestic vectors and the screening of blood donors in Argentina, Brazil, Chile, Paraguay and Uruguay. Uruguay was declared free of Chagas disease transmission by Triatoma infestans in 1997, Chile in 1999 and Brazil in 2006. Transmission has been effectively eliminated also in substantial 


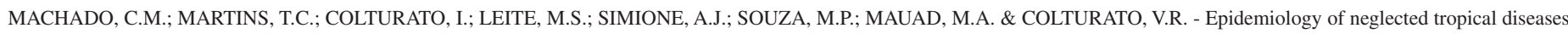
in transplant recipients. Review of the literature and experience of a Brazilian HSCT center. Rev. Inst. Med. trop. S. Paulo, 51(6): 309-324, 2009.

areas of Argentina, Bolivia and Paraguay. Similar initiatives took place in 1997 for the Central America and Andean Pact countries, and in 2004 for the nine countries of the Amazon basin ${ }^{93}$. Thus, global disease prevalence has been reduced from the 1990 estimates of 16-18 million people infected to $9-12$ million $^{93}$.

3.2. Transmission in transplant recipients: Transplant recipients from non-endemic countries are more likely to acquire T. cruzi infection through blood transfusion or by an infected graft, while infected recipients from endemic regions are at risk of reactivation of latent infection during immunosuppression.

Currently, migration within and beyond endemic countries is the main factor in Chagas disease transmission. According to the 2000 US census, over 16 million foreign born were from Latin America, representing 52\% of the total foreign-born population residing in the United States ${ }^{69}$. An estimated 100000 infected persons live in the US; most acquired the disease while residing in endemic areas from origin countries. In Europe, the number of immigrants from these areas has increased significantly in recent years. In some countries, the immigrant population has doubled in the last five years as observed in Spain, where it accounts for nearly $8 \%$ of the total population (more than 50\% coming from Central and South America $)^{25}$. In 2006, the US Food and Drug Administration approved the Ortho T. cruzi ELISA Test System to screen blood donors in the United States. By mid 2008, more than 500 confirmed T. cruzi-infected donations were reported ${ }^{12}$.

3.2.1. Blood-borne transmission: The risk of transmission of the infection after transfusion of a contaminated blood unit has been estimated to be around $20 \%{ }^{92}$. The first report of transmission via an infected blood transfusion was in Brazil in 1952. Since then, more than 200 cases of transfusional Chagas disease have been reported in Latin America $^{70}$. In North America and Mexico, seven cases of transfusionassociated Chagas disease have been documented in the past 20 years and this number is possibly underestimated. All cases occurred in immunocompromised patients and the disease may be asymptomatic or oligosymptomatic in immunocompetent patients ${ }^{13}$. In 1989, a fatal case of acute Chagas disease transmitted by blood transfusion was reported in a renal transplant recipient in Chile ${ }^{101}$.

3.2.2. Transmission via graft: The first strong evidence of transmission via graft was reported in Brazil in 1983. Four renal transplant recipients developed Chagas disease, all four had received graft from infected donors in chronic phase of $T$. cruzi infection ${ }^{24}$. Other series have been published, mostly from Argentina and Brazil, which perform the greatest number of renal and liver transplants in South America ${ }^{19,29,87,96}$. In the US, three cases of T. cruzi transmission via graft were reported to the CDC in 2001. Three SOT recipients, one liver and two renal, who received the organs from the same donor developed Chagas disease ${ }^{41}$. Other two cases were reported in 2006, both in heart transplant recipients. The investigation of the source of infection in both cases showed that all available blood donors tested seronegative for $T$. cruzi but the organ donors tested positive by the radioimmunoprecipitation assay ${ }^{22}$.

3.2.3. Reactivation: Higher rates of reactivation are expected to occur after heart transplantation. A recent study evaluated the risk factors for Chagas' disease reactivation, which occurred in $26.5 \%$ of previously infected heart transplant recipients. Multivariate analysis showed that the number of rejection episodes, neoplasms and use of mycophenolate mofetil were the risk factors independently associated with reactivation ${ }^{18}$. In Argentina, where blood monitoring is routinely performed in SOT and HSCT recipients with previous $T$. cruzi infection, reactivation rates of $9 \%$ to $16 \%$ have been observed in kidney transplantation, $50 \%$ to $100 \%$ in heart transplantation, and $17 \%$ to $40 \%$ in autologous and allogeneic $\mathrm{HSCT}^{4}$.

Pre-transplant treatment in transplant candidates with Chagas disease has been suggested in a recent review ${ }^{11}$. However, experts from endemic countries who have managed these patients for decades consider that T. cruzi monitoring in blood, followed by pre-emptive introduction of benznidazole is safe ${ }^{4}$.

3.3. Recommendations: Donor/recipient pre-transplant investigation of history of living in endemic areas for Chagas disease is mandatory. Serological tests for $T$. cruzi are recommended in these cases. Two positive results in different serological techniques are necessary to consider a patient to be infected.

- Donors who died of acute Chagas disease should be excluded. In the case of cardiac transplantation, the use of a heart from a patient with chronic Chagas disease is an absolute contraindication due to the risk of chagasic myocarditis during the period of immunosuppression.

- In Latin America, donors chronically infected by T. cruzi are not excluded from donation of other organs, except heart. However, a close follow-up with serological and parasitological methods is strongly recommended and immediate treatment with benznidazole for 30 to 60 days or nifurtimox for 90 to 120 days should be started if parasitemia is detected.

- The recommendation for prophylaxis is controversial both in cardiac or other transplant recipients ${ }^{4,14}$. For patients with chagasic cardiomyopathy who undergo cardiac transplantation from a healthy donor, prophylactic treatment to prevent disease reactivation should be considered. In other transplant recipients, early treatment should be started if there is evidence of reactivation.

\section{Leishmaniasis}

The term leishmaniasis designates a group of diseases caused by the genus Leishmania. Leishmaniasis is primarily a zoonotic infection, but anthroponotic forms of the disease have been increasingly observed as humans enter the transmission cycle of the parasite and get infected. In anthroponotic forms, man is the sole source of infection for the vector.

The protozoan is transmitted to humans through the bite of an infected female mosquito from the genus Phlebotomus (in the Old World) or Lutzomya (in the New World). However, incidental transmission by blood transfusions or by needle sharing among intravenous drug addicts has also been described ${ }^{28,59}$.

There are two main clinical presentations of the disease, cutaneous or mucocutaneous leishmaniasis (CL) and visceral leishmaniasis (VL), also known as Kala azar. Cutaneous forms can be localized, producing ulcers which usually heal within few months, or disseminated with chronic skin lesions resembling lepromatous leprosy, difficult to treat. In 


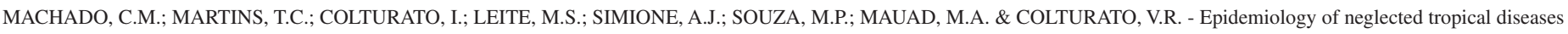
in transplant recipients. Review of the literature and experience of a Brazilian HSCT center. Rev. Inst. Med. trop. S. Paulo, 51(6): 309-324, 2009.

mucocutaneous forms the lesions usually destroy the mucous membranes of the nose, mouth and throat ostracizing the victims from the society due to obviously cosmetic and psychological problems. VL is characterized by high fever, substantial weight loss, anemia and swelling of the spleen and liver. If untreated, mortality rates as high as $100 \%$ have been reported. Malnutrition is a well-known risk factor in the development of Kala azar.

In the Old World, CL are caused by Leishmania tropica, L. major and L. aethiopica, and VL are caused by the Leishmania donovani complex. In the Americas, various leishmania species are able to produce cutaneous leishmaniasis, such as: L. braziliensis, L. amazonensis, L. guianensis, $L$. pananmensis and L. mexicana. Visceral leishmaniasis in the New World is caused by L. chagasi ${ }^{61}$.

Since 1993, a sharp increase in the number of cases as well as a significant expansion in the geographical distribution has been documented in many countries. Cutaneous leishmaniasis has increased almost two times in Brazil from 1998 to 2002; four times in Afghanistan from 1994 to 2002, and almost 85 times in Burkina Faso. Visceral leishmaniasis increased three times in the North-eastern Brazil from 1998 to $2002^{33,34}$. The main reasons for this increase are migration and urbanization. Socio-economic, religious, political and environmental factors have forced people to abandon their villages and move to the suburbs of cities, in which the poor sanitary conditions and the close contact with domestic dogs create an ideal environment for the Phlebotomus and Lutzomya species.

4.1.Geographic distribution: Leishmaniasis is prevalent in four continents and considered endemic in 88 countries, 72 of which are developing countries: $90 \%$ of all visceral leishmaniasis occur in Bangladesh, Brazil, India, Nepal and Sudan; $90 \%$ of mucocutaneous leishmaniasis occur in Bolivia, Brazil and Peru and 90\% of CL occur in Afghanistan, Algeria, Brazil, Iran, Peru, Saudi Arabia and Syria ${ }^{33}$.

An estimated 12 million people are presently infected worldwide. The global number of new cases of CL and VL each year is estimated in about 1.5 million and 500,000, respectively. It is probable that the number of new cases is underestimated as declaration is compulsory in less than half of the countries affected by leishmaniasis.

The control of leishmaniasis is based in the control of the anthroponotic foci which are the source of severe and life-threatening VL epidemics. Dogs are the main source of infection and canine enzooty usually precede the occurrence of cases in humans. Policies include early treatment of humans cases of VL, passive and active notification of canine leishmaniasis, vector control, use of screens in doors and windows, continuous education, and if necessary, humanitarian elimination of infected dogs.

4.2. Transmission in transplant patients: According to a recent review, 79 cases of leishmaniasis have been described in organ transplant recipients from countries of four continents 5 . More than two-thirds of theses cases were from Spain, Italy and France. Due to the lower number of publication in developing countries, the number of reported cases is certainly underestimated in these places. The risk of leishmaniasis among transplant recipients is associated with the geographic region in which donor and recipient live. However, few cases have been reported in transplant recipients from non-endemic areas that traveled to an endemic region of leishmaniasis ${ }^{47,52}$.
Most of the cases are described in renal transplant recipients (77\%) possibly reflecting the greater number of renal as compared to other organ transplants worldwide. In this setting, leishmaniasis appears at a median of 19 months after transplantation. Among liver transplant recipients, leishmaniasis manifests earlier (median six months). Visceral leishmaniasis is the most frequent clinical presentation, being reported in $86 \%$ of the cases. Cutaneous leishmaniasis is rare and two cases were reported of classical disease, one case of disseminated disease, one case of nodular disease and two cases of post-Kala azar dermal leishmaniasis ${ }^{5}$.

Leishmaniasis in transplant recipients may occur due to 1) reactivation of latent infection in a previously infected recipient during immunosuppression; 2) de novo infection in transplant recipients living in or traveling to areas of endemicity ${ }^{6} ; 3$ ) transfusion-associated leishmaniasis, as routine serology for blood or organ donors is not performed even in areas of high endemicity ${ }^{59}$; 4) via an infected graft, as asymptomatic infection is more frequent than symptomatic disease even in endemic areas ${ }^{5}$. This route of transmission is more likely to occur in organs that form part of the reticuloendothelial system, such as liver.

4.3. Recommendations: Since no prospective studies are available, the real incidence, risk factors, morbidity and mortality of cutaneous and visceral leishmaniasis in different transplant populations, are unknown. Consequently, based on current data, few recommendations can be made:

- Leishmaniasis should be investigated in patients with persistent fever and pancytopenia, in patients who live in or have traveled to endemic areas of the disease.

- Routine serological screening of organ donors from endemic countries is currently not recommended. If a donor is known to be positive, monitoring of the recipient in the post-transplant period is advised. Serology and direct detection of leishmania amastigotes in bone marrow biopsy samples should be performed in suspected cases. PCR detection has been regarded as the method of choice for the diagnosis and follow-up of VL transplant recipients ${ }^{5}$.

\section{Malaria}

Malaria is an acute systemic illness caused by infection with Plasmodium falciparum, Plasmodium vivax, Plasmodium malariae, or Plasmodium ovale. $P$. falciparum tends to be more virulent than other species.

Currently, half of the world population is at risk, as 109 countries are endemic for malaria. An estimated 247 million cases were reported in 2006, causing nearly a million deaths, mostly of children under five years ${ }^{7}$.

Plasmodium species are transmitted to humans by female Anopheles mosquitoes. The life cycle of the parasites has two phases; an asexual replicative phase in humans and a phase of sexual replication in the mosquito. In the human body, the parasites multiply in the liver, and then infect red blood cells. The symptoms, signs, and pathological features of malaria are caused by the asexual erythrocytic stage of the parasites which invade and replicate in erythrocytes over two to three days, rupture these cells and reinvade normal erythrocytes. This exponential parasite replication in the bloodstream increases parasite density by 5 to 30 -fold 


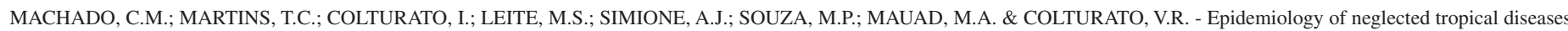
in transplant recipients. Review of the literature and experience of a Brazilian HSCT center. Rev. Inst. Med. trop. S. Paulo, 51(6): 309-324, 2009.

every two to three days. In the case of $P$. vivax and $P$. ovale, a proportion remains dormant (hypnozoites) inside the hepatocytes and these forms are responsible for late relapses ${ }^{70}$.

The global control of malaria include prompt treatment with artemisinin-based combination therapies; use of insecticidal nets by people at risk; and indoor spraying with insecticide to control the vector mosquitoes.

5.1. Geographic distribution: Malaria cases have been reported in Central and South America, sub-Saharan Africa, India, Southeast Asia and part of Oceania. Awareness of Plasmodium species endemicity is important to early introduction of appropriate treatment. Plasmodium falciparum is found in sub-Saharan Africa, Southeast Asia, and the Indian subcontinent as well as in South America, Haiti, the Dominican Republic, Jamaica and areas of Oceania. $P$. malariae and $P$. ovale are present in sub-Saharan Africa. Plasmodium vivax is prevalent in areas of Southeast Asia, the Indian Subcontinent, and Central and South America ${ }^{70}$. Malaria is the most frequent cause of systemic febrile illness among ill travelers returning from the developing world ${ }^{40}$.

5.2. Transmission in transplant recipients: In transplant recipients, malaria may be transmitted through infected blood products, by natural exposure to Plasmodium infected mosquitoes in endemic regions, or via an infected organ. The washing of organ blood during the transplantation procedure may not be enough to eliminate possibly parasitized red cells within the organ and transmission may occur. In transfusion associated malaria, symptoms generally develop earlier (one to three days) than if the infection is transmitted through infected cells within the organ (more than one week) ${ }^{70}$.

Plasmodium species are capable to survive more than 24 hours in blood at $4{ }^{\circ} \mathrm{C}$. Therefore, the time of cold preservation is generally not enough to prevent transmission, especially in heart and liver transplantation that require shorter cold preservation time: three to four hours for heart and less than 12 hours for liver, in comparison to 24 to 48 hours for kidney. The reports of malaria cases following multiorgan donation have supported the hypothesis of the graft as a source of Plasmodium in transplant recipients ${ }^{23,39,72}$. Malaria deaths in SOT recipients are generally associates with $P$. falciparum infection.

Past geographic exposure of both donor and recipients seems to be the main source of Plasmodium infection in HSCT recipients, even though transmission by blood transfusion has also been reported ${ }^{80,104}$. In most cases, the diagnosis was made by the identification of the parasite in blood smears of febrile patients with unexplained hemolysis and thrombocytopenia.

Clinicians caring for transplant recipients in developing countries of known endemicity should take into account that the parasite may persist in humans who survived to untreated malaria. Persistence is estimated to be one year for $P$. falciparum, three to five years for $P$. vivax and ovale and as long as 40 years for $P$. malariae. Immunosuppression may well facilitate parasite reactivation and cases of severe malaria have possibly been misdiagnosed in this population.

5.3. Recommendations: Investigation of the epidemiological risk for malaria is mandatory for both donors and recipients in endemic regions.
If possible, routine serology and blood smear examination should be considered for all patients and donors with exposure risk. In developing countries, a past history of malaria is not a contraindication for organ or stem cell donation.

- Clinicians must be aware that malaria not always has the typical paroxysmal or cyclic pattern in transplant recipients and a high index of suspicion should be maintained when caring for patients with identifiable risk factors. Especial attention should be paid to splenectomized patients who may develop more severe disease because the spleen is responsible for the removal of parasitized cells from the circulation.

- If donors or recipients have history of mosquito exposure in regions of Plasmodium vivax or $P$. ovale, clinicians should have in mind that the parasites' exoerythrocytic schizogeny in the liver makes eradication more difficult. These dormant hypnozoites forms can cause relapse up to 12 months later.

- Guidelines from developed countries recommend that persons from non-endemic areas should be deferred from HSCT donation if they have traveled to an endemic region in the past 12 months. Similarly, persons who have had malaria and received appropriate treatment should wait at least three years for donation. In endemic countries, those deferral times are not feasible in the transplant setting. Thus, the donor should receive empiric treatment for malaria prior to donating ${ }^{102}$.

\section{Dengue}

Dengue is definitely the most common mosquito-borne viral disease of humans causing a severe flu-like illness, and sometimes potentially lethal complications such as dengue hemorrhagic fever (DHF) and dengue shock syndrome (DSS). Dengue occurs both as an endemic or epidemic disease. In tropical and subtropical areas, dengue is endemic in 112 countries $^{109}$. An estimated 2.5 billion people live in areas where dengue viruses can be transmitted.

There are four closely related viruses that cause dengue (DEN1, DEN2, DEN3 and DEN4) which belong to the Flaviviridae family, genus Flavivirus, which are transmitted by mosquitoes of the genus aedes, such as Aedes aegytpi and Aedes albopictus.

In the last two decades, dengue incidence has grown dramatically, due to the expanding geographic distribution of the virus and the mosquito vector, the increased frequency of epidemics, the cocirculation of multiple virus serotypes and the emergence of DHF in new areas ${ }^{45,109}$. Urbanization with poor living conditions, lack of vector control, climatic change, virus evolution and international travel are probable reasons for this resurgence ${ }^{109}$. The recent reemergence of dengue fever in Easter Island exemplifies the role of air travel in this situation ${ }^{31}$. Currently, dengue is the most frequent disease diagnosed in travelers returning from Caribbean, South America, and South, Central and Southeast Asia ${ }^{40}$.

In 2006, more than one-half million cases of dengue fever were reported as well as 14,459 cases of dengue hemorrhagic fever (DHF) ${ }^{48}$. Sixty-three percent of all dengue cases in Latin America occurred in Brazil, a number highly underestimated according to seroprevalence 


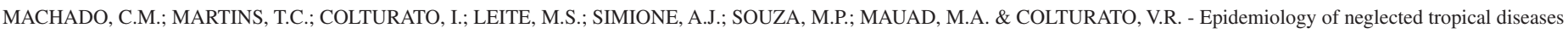
in transplant recipients. Review of the literature and experience of a Brazilian HSCT center. Rev. Inst. Med. trop. S. Paulo, 51(6): 309-324, 2009.

studies $^{38}$. In the same country, while the number of classic dengue fever increased three times from 2000 to 2002, DHF cases increased 45-fold in the same period. In 2002, 150 deaths due to DHF were reported and, for the first time, exceeded the absolute number of malaria deaths ${ }^{103}$. In 2007, the number of classic dengue fever increased to 559,954, with 1,541 cases of DHF and 158 fatalities. Up to September 2008, 240,411 cases of dengue and 169 deaths had been registered only in the state of Rio de Janeiro, the final destination of great number of tourists visiting Brazil.

Infection by one serotype provides lifelong immunity against that serotype but only partial and transient protection against subsequent infection by the other three. In the immunocompetent population, there is good evidence that sequential infection increases the risk of more serious disease resulting in DSS or $\mathrm{DHF}^{46}$. Patients with DSS or DHF have elevated circulating levels of T-cell activation markers, such as interleukin-2, interferon- $\gamma, \mathrm{CD} 4, \mathrm{CD} 8$ and soluble IL-2 receptor. Therefore, a robust immunologic response is a pre-requisite for the development of DHF or DSS.

6.1. Geographic distribution: The main vector, Aedes aegypti and the viruses are spread in tropical and subtropical areas in Central and South America; Central, East and West Africa; East, Southeast and South Asia, Middle East; South Pacific and Northeast Australia. Since 2001, all four dengue virus serotypes have circulated regularly in the Americas. DEN4 has circulated in most countries of Central America, but only in two South America countries (Peru and Venezuela).

6.2. Transmission in transplant recipients: Several countries in the aforementioned regions have active transplant programs. However, few cases of dengue have been reported in haematopoietic stem cell and solid organ transplant recipients. The disease has certainly been underdiagnosed in transplant population from endemic areas, since most of the cases are mild and presenting as a flu-like syndrome. The actual number of infections in a population may be five to 10 times greater than the number reported, as persons with milder illness may not seek medical attention and the opportunity of diagnosis is $\operatorname{lost}^{10}$. In addition, the paucity of reports of DHF or DSS in transplant recipients may reflect the T-cell immunosuppression induced in this population and the consequent low inflammatory response.

The transmission of dengue in transplant recipients living or traveling to endemic areas is by far via mosquito bite. According to the published cases, most of the transplant recipients were living in endemic $\operatorname{areas}^{8,21,42,82,86}$ and acquired dengue by vector transmission. One case was diagnosed after returning from a travel to South Asia ${ }^{82}$.

Dengue transmission via graft has also been reported ${ }^{88,98}$. In 2001, RIGAU-PÉREZ et al. described a case of dengue in a bone marrow transplant recipient during the 1994-1995 dengue epidemics in Puerto Rico. The patient, a 6-year old child, died eleven days after transplantation and DEN4 was detected in blood, ascitic fluid and tissue samples. The donor developed fever two days after marrow harvesting and dengue was diagnosed by the presence of specific IgM antibodies. DEN4 serotype was confirmed in donor samples ${ }^{88}$. TAN et al. reported a case of dengue hemorrhagic fever in a renal transplant recipient who received a possibly infected allograft from a living donor who had a past history of dengue. Since there was no active transmission of dengue in the area during the period, the authors hypothesized that the graft was the source of the infection $^{98}$.

In three case-reports of dengue in liver, renal and HSC transplant recipients, the patients had severe disease and died, two of them from dengue shock syndrome ${ }^{21,42}$. The HSCT recipient apparently had disseminated infection but the authors did not mention the hemodynamic evolution of the patient ${ }^{88}$. However, in the published case series of dengue from Brazil (27 cases) and Singapore (six cases), both in renal transplant recipients, a benign course was generally observed and death probably due to dengue shock syndrome was registered in one of the 27 patients (3.7\%) from the Brazilian series ${ }^{8,86}$. Dengue mortality rates vary from $0.026 \%$ in classic dengue fever up to $5 \%$ in DHF in the immunocompetent population.

6.3. Recommendations: No prospective seroepidemiological study has been performed in transplant recipients from endemic areas. Thus, the actual incidence, morbidity and mortality of dengue fever and its complications are difficult to estimate. Dengue control is based on vector control and community-based programs to keep the environment free of potential breeding sources, mainly artificial water containers such as discarded tires, uncovered water storage barrels, buckets, flower vases, etc $^{10}$. The mosquitoes breed in limpid water.

Based on the available data, a few recommendations can be made:

- In endemic regions, transplant patients should receive information about dengue transmission and Aedes habits to avoid exposure. In these areas, the inclusion of dengue in the diagnostic assessment of transplant patients with fever and thrombocytopenia is recommended. Clinicians should have a high index of suspicion for DHF in transplant recipients with hemorrhagic fevers.

- During epidemics, the cost benefit of screening donors of organs and blood products in hyperendemic regions needs to be assessed. Studies conducted during epidemics have detected DEN viremia by PCR in $0.04 \%$ to $0.3 \%$ of in asymptomatic blood donors ${ }^{62,77}$.

- Transplant travelers to endemic and epidemic areas should take precautions to avoid mosquito bites and consult a travel disease specialist to receive information about Aedes aegypti habits. The mosquitoes bite generally during daylight hours, different from other disease vectors such as the Anopheles (malaria).

\section{Yellow fever}

Yellow fever is a vector-borne disease caused by yellow fever virus (YFV), a RNA virus belonging to the family Flaviviridae, genus Flavivirus, transmitted to humans by the bite of infected mosquitoes. YFV infects humans and monkeys in three types of transmission cycle: sylvatic (jungle), savannah and urban.

After an incubation period of three to six days, immunocompetent patients develop fever, muscle pain, headache, shivers, loss of appetite, nausea and vomiting, characterizing the acute phase of yellow fever. Most patients improve and symptoms disappear in few days. Around $90 \%$ of the cases are mild or asymptomatic. However, in a few cases, the disease progress to a toxic phase with reappearance of fever and the 


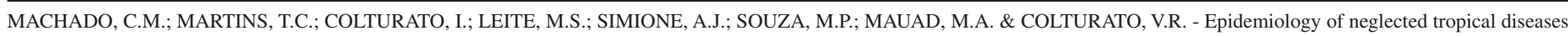
in transplant recipients. Review of the literature and experience of a Brazilian HSCT center. Rev. Inst. Med. trop. S. Paulo, 51(6): 309-324, 2009.

development of jaundice and sometimes bleeding. About $50 \%$ of patients in toxic phase die within 10 to 14 days ${ }^{107}$.

The control of yellow fever is based on mosquito eradication and vaccination of people living in or traveling to risk areas.

7.1. Geographic distribution: Yellow fever occurs as endemic and intermittently epidemic disease in sub Saharan Africa and in tropical rainforests of South America. Sporadic cases are reported in some countries of Central America and Caribbean islands. Fatal cases of yellow fever have been reported among unvaccinated tourists from the United States and Europe who visited endemic areas of yellow fever ${ }^{20,78}$.

The vast majority of the cases and deaths are from sub-Saharan Africa, responding for more than $90 \%$ of the cases reported to the World Health Organization (WHO) ${ }^{107}$. From 1965 to 2004, 33,381 cases of yellow fever were reported to the $\mathrm{WHO}^{9}$. In South America, an average of 160 cases of jungle yellow fever is reported to the WHO each year, with a case fatality rate of $65 \%$. More than $50 \%$ of the cases are from Peru, followed by Bolivia and Brazil. From 2007 to 2008, an increase in the incidence of sylvatic YF was observed in Brazil with 45 confirmed cases and 25 deaths ${ }^{75}$.

Aedes aegypti has biological and behavioral characteristics which enabled it to expand its geographic distribution both in urban and rural areas. This mosquito is once again infesting regions from which it was previously eradicated. Thus, there is a great concern about the resurgence of urban yellow fever in cities infested by Aedes aegypti and close to the sylvatic cycle of the YFV 9 .

7.2. Transmission in transplant patients: No case of yellow fever has been reported in solid organ or stem cell transplant recipients. However, the occurrence of the disease in the transplant population in developing countries can be just a matter of time, in the case of urban yellow fever resurgence. The following information may be helpful for clinicians assisting transplant recipients:

- The live-attenuated yellow fever vaccine is contraindicated in transplant recipients due to the potential risk of severe adverse events, mainly encephalitis ${ }^{20,36}$. More than 20 cases of YF vaccination has been reported in a HSCT recipient without side effects ${ }^{64}$.

- In Brazil, vaccination is considered according to the risk of yellow fever and patient immunological status. Solid organ transplant candidates from endemic regions are recommended to vaccinate before transplant. Vaccine is also considered for HSCT recipients not using immunosuppressive drugs, after the second year of transplant and living in areas of great risk of yellow fever. In other circumstances vaccination is contraindicated and should be avoided ${ }^{94}$.

- In endemic states of Brazil, yellow fever vaccine is routinely administered to children at nine month of age and every 10 years. Although serological studies have not been conducted in transplant population from endemic areas, SOT recipients vaccinated regularly before transplantation may theoretically hold some specific immunity. Similarly, specific immunity may be transferred to allogeneic HSCT recipients from vaccinated donors. The duration of yellow fever immunity in HSCT recipients previously vaccinated is unknown.
- Vaccine strain viremia frequently occurs in healthy persons during the first week of primary yellow fever vaccination. In booster doses, vaccine strain viremia is unlikely ${ }^{20,85}$. In the case of donor vaccination, it is prudent to wait at least one week to stem cell or marrow harvesting or organ donation.

- Transplant recipients from developed countries traveling to endemic regions of yellow fever should be advised of the risks posed by such travel, instructed in methods for avoiding vector mosquitoes, and supplied with vaccination waiver letters by their physicians ${ }^{20}$.

7.3. Current concerns and other information: Although yellow fever has never been reported in Asia, the potential for outbreaks exists as the appropriate mosquito is present, and international travels connect cities worldwide.

Restricted mass campaign vaccination is considered whenever epizootic outbreaks in monkeys are detected. In 2008, mass vaccination targeting approximately seven million people was performed in most affected states of Brazil, one of three WHO pre-qualified manufacturers of yellow fever vaccine. To meet the country needs in response to this outbreak, Brazil suspended exports of the vaccine and borrowed an additional four million doses from the global emergency stockpile managed by the International Coordinating Group on Vaccine Provision for Yellow Fever Control ${ }^{75}$. These facts exemplify the eminent risk of vaccine shortage in the case of urban YF outbreaks in populous countries.

\section{Measles}

Measles is an acute illness caused by a virus belonging to the Paramyxoviridae family, which infects primate species, but can only be maintained in human populations. The virus spreads from person to person within aerosol droplets generated during coughing. Characteristic symptoms such as fever, dry cough, coryza, rash, conjunctivitis and photophobia initiate 10 days after infection ${ }^{89}$. Measles is one of the most contagious diseases as almost all susceptible persons acquire the disease once exposed to the virus. Consequently, measles tends to result in epidemics that cause many deaths, especially among young malnourished children.

Vaccination is the best way to control measles and has a major impact on measles deaths. A safe and effective live-attenuated virus vaccine is available for the past 40 years. Although measles elimination has been declared in the US in 2000 and in the Americas in 2002, approximately 20 million cases of measles occur each year worldwide ${ }^{106}$. Sustained elimination requires the maintenance of high measles vaccine coverage rates, more than $90 \%$ one-dose coverage among preschool children and more than $95 \%$ two-dose coverage among school-aged children ${ }^{44}$.

In 1998, mass campaign vaccination and other measles control activities were initiated in developing countries with the highest burden of measles. Global measles mortality decreased by $68 \%$ between 2000 and 2006, having the highest gains occurred in Africa where measles cases and deaths fell by $91 \%{ }^{112}$.

8.1. Geographic distribution: Measles has not been eliminated from most countries and is the first disease to reappear when vaccine coverage falls. Africa has the greatest number of reported cases and deaths annually. 


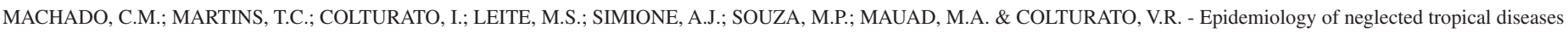
in transplant recipients. Review of the literature and experience of a Brazilian HSCT center. Rev. Inst. Med. trop. S. Paulo, 51(6): 309-324, 2009.

Forty-seven countries account for more than $95 \%$ of the global measles deaths: 31 of them $(66 \%)$ are in Africa, six in eastern Mediterranean region, six in Southeast Asia and four in Western Pacific region.

As a result of decreased measles vaccination coverage, developed countries have also registered epidemics of measles in recent years: Ireland and the Netherlands in 2000, Korea in 2001, Italy in 2002, Switzerland in 2006, Japan in 2007, and United States in 2008.

8.2. Transmission in transplant patients: As measles epidemics resurge, susceptible transplant recipients from developed and developing countries become an easy target for measles and its complications. Previous and/or donor-transferred immunity wanes over time and measles antibodies titers are expected to fall below the protective level during follow-up. Up to $55 \%$ of HSCT and $22 \%$ of SOT recipients lose measles immunity by 24 and six months after transplant, respectively ${ }^{68,108}$.

Protection against measles in transplant recipients strongly relies on herd immunity, since live-attenuated vaccines have restricted use in this population. In SOT recipients, measles vaccination is recommended before the transplant, and in the setting of HSCT, measles vaccine can be safely used after 24 months of transplantation in patients not receiving immunosuppressive drugs ${ }^{63}$.

Measles has been diagnosed in transplant patients as a result of community outbreaks. The largest series of measles cases in transplant population was described in HSCT recipients during an outbreak in Brazil. In view of the limitations to the use of live-attenuated vaccines in these patients, a serological survey was performed and identified 54 susceptible to measles, eight of which acquired measles in the first three months of the outbreak (attack rate 14.8\%). One patient developed measles pneumonia. No patient developed CNS complications during follow-up or died of measles ${ }^{68}$. More recently, one fatal case of measles pneumonia was reported in a 39-year old HSCT recipient with chronic GVHD, during the 2000-2001 measles epidemics in Korea ${ }^{60,113}$.

In the setting of solid organ transplantation, five cases of measles associated encephalitis have been reported in renal transplant recipients, at a median of five years after transplantation (range three to 11 years $)^{2,53,56,105}$. Preceding measles infection was reported in three of the five patients, six weeks to four months before the appearance of neurological symptoms. In the remaining two patients, measles diagnosis was retrospectively performed by serology in one case and by necropsy in the other case. Patients' age vary from eight to 21 years and three of them had received one dose of measles vaccine in infancy. One patient had not been vaccinated and in the remaining one, vaccination status was not informed. Three patients $(60 \%)$ died as a consequence of CNS complications and the other two patients survived with sequelae ${ }^{105}$. Since disease can be mild or follow an atypical course, measles has possibly been underdiagnosed in solid organ transplant recipients.

8.3. Use of measles vaccine in special circumstances: The use of live-attenuated measles vaccine is restricted in transplant populations. However, there is growing evidence of its safety in situations where the risk of measles complications outweighs the risk of adverse events of vaccination.

Measles vaccine administered after the $12^{\text {th }}$ month of transplant was safe and effective during the 1997-1999 measles epidemics in Brazil. Around $53 \%$ of the patients were receiving immunosuppressive drugs. No moderate or severe adverse events were observed and vaccination was the strategy used to interrupt measles transmission among susceptible HSCT recipients ${ }^{67}$.

The safety of measles vaccine beyond its recommended use has also been evaluated after solid organ transplantation. In two studies recently reviewed ${ }^{66}, 31$ patients received measles vaccination between 1.5 to 65 months after transplantation. No adverse event was noted among 29 children. In the remaining two children (6.4\%), signs of organ rejection were observed three weeks after first vaccination, but the possible association of vaccination and rejection remains elusive. Seroconversion rates were higher in patients who had received measles vaccine before transplant $(85 \%)$ as compared to children immunized only after transplantation (41\%). Similarly, sustained immunity was observed in $64 \%$ of the patients previously vaccinated in comparison to $29 \%$ of the patients who were vaccinated only after transplantation ${ }^{54,66,84}$. In another study, overall responses rates of $73 \%$ were observed in 26 children receiving primary measles vaccination after liver transplantation. However, 18 patients required multiple doses ${ }^{55}$.

8.4. Current concerns and recommendations: Due to the high attack rate of measles, the disease has reappeared in developed countries. Fourteen years after elimination, measles is again endemic in the United Kingdom because of a drop in vaccination coverage levels around $80 \%-85 \%$ in children aged two years ${ }^{37}$. The decrease in coverage rates in developed countries and the following outbreaks occurred mainly because parents choose not to vaccinate their children. This attitude exposes susceptible persons to a measles risk that hits harder the immunocompromised host who depend on herd immunity for protection against measles. Since April 2008, two measles-related deaths have been reported in Europe in immunocompromised patients ineligible to receive measles vaccine ${ }^{106}$.

- Clinicians should have a high index of suspicion for measles in transplant recipients with respiratory symptoms during epidemics as rash may be absent or atypical.

- Compliance to vaccination guidelines is strongly recommended in both SOT and HSCT recipients. Periodical evaluation of measles immunity identifies susceptible patients eligible to revaccination.

- In epidemic situation when the risk of measles complications may overweigh the risk of adverse events, measles vaccination should be considered to individuals receiving immunosuppressive drugs.

\section{THE EXPERIENCE OF THE HSCT PROGRAM OF AMARAL CARVALHO FOUNDATION}

The HSCT program of Amaral Carvalho Foundation was started in August 1996 and currently is the greatest Brazilian program for allogeneic transplants. The HSCT unit is located at Amaral Carvalho Hospital, a tertiary 303-bed public hospital, in the city of Jaú, SP, Brazil. In recent years, an increasing number of transplants have been performed at the HSCT program of Amaral Carvalho Foundation and presently, around 170 procedures are performed per year. Transplant candidates come from the majority of the states of Brazil, including the Amazon rain forest, and all live in endemic areas for one or more NTDs (Fig. 1). 


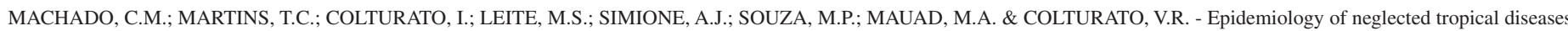
in transplant recipients. Review of the literature and experience of a Brazilian HSCT center. Rev. Inst. Med. trop. S. Paulo, 51(6): 309-324, 2009.

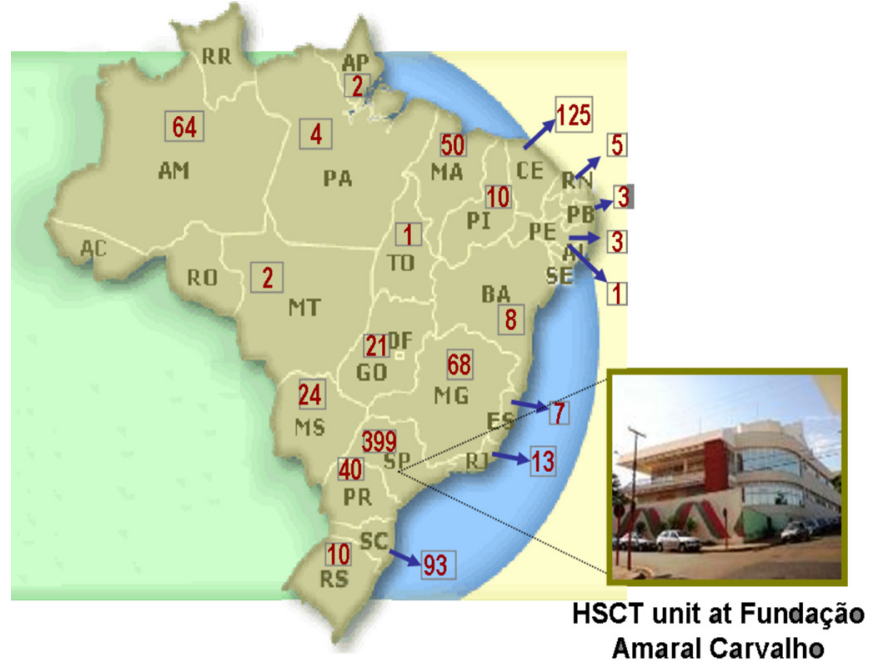

Fig. 1 - Political map of Brazil showing the number of patients who received HSCT at Amaral Carvalho Foundation in Jaú, SP.

NTD search strategy: Retrospective review of the charts of HSCT recipients from August 2006 to March 2008, and the relevant information about the occurrence or the risk for both donors and recipients to develop a NTD.

Firstly, the pre-transplant visit questionnaires were revised to check for past history of neglected tropical diseases. Secondly, we reviewed donor and recipient serological data for Chagas disease. Lastly, the charts were carefully revised for the occurrence of NTDs during follow-up.

As an expanding distribution of yellow fever (YF) was observed during the study period, patients living in endemic areas were taken blood samples to check for specific antibodies and to evaluate the need of YF immunization. Information about previous yellow fever vaccination was obtained by written reports or telephone calls. YF serology was performed at Fundação Oswaldo Cruz (FIOCRUZ), in Rio de Janeiro.

All gathered information was transcribed to a database. Soiltransmitted helminth infections were not investigated as empiric treatment with albendazole and mebendazole is performed in all transplant candidates.

\section{RESULTS}

The assessment of pre-transplant questionnaires showed that only the epidemiological risks for Chagas disease and malaria were inquired. Other NTDs were not spontaneously reported. No tuberculin skin test (TST) was performed before HSCT and no latent TB infection (LTBI) was suspected.

Nine hundred and fifty three charts were reviewed comprising 296 autologous transplants, 542 allogeneic (related donor), 70 (unrelated donor) and four syngeneic. Forty-one patients had a second transplant. Patient's characteristics are shown on Table 2.

The NTDs identified in the present series as well the risk for their occurrence in donors and/or recipients were: Leprosy, tuberculosis,
Table 2

Patient characteristics $(n=953)$

\begin{tabular}{|c|c|c|}
\hline \multicolumn{2}{|l|}{ Variable } & \multirow{2}{*}{$\frac{\mathbf{n}(\%)}{32.5(0.03-65.9) \mathrm{yr}}$} \\
\hline $\begin{array}{l}\text { Median age } \\
\text { (range) }\end{array}$ & & \\
\hline Gender & Male / female & 549 (57.6) / $404(42.4)$ \\
\hline \multirow[t]{5}{*}{ HSCT type } & Allogeneic RD & $542(56.9)$ \\
\hline & Allogeneic URD & $70(7.3)$ \\
\hline & Autologous & $296(31.1)$ \\
\hline & Syngeneic & $4(0.4)$ \\
\hline & Retransplants & $41(4.2)$ \\
\hline \multirow[t]{4}{*}{ Stem cell source } & PBSC & $591(62)$ \\
\hline & $\mathrm{BM}$ & $300(31.5)$ \\
\hline & $\mathrm{CB}$ & $35(3.7)$ \\
\hline & $\mathrm{BM}+\mathrm{PBSC}$ & $27(2.8)$ \\
\hline \multirow[t]{8}{*}{$\begin{array}{l}\text { Underlying } \\
\text { diseases }\end{array}$} & $\begin{array}{l}\text { Chronic myelogenous } \\
\text { leukemia }\end{array}$ & $221(23.2)$ \\
\hline & $\begin{array}{l}\text { Acute myelogenous } \\
\text { leukemia }\end{array}$ & $219(23)$ \\
\hline & Multiple myeloma & $140(14.7)$ \\
\hline & $\begin{array}{l}\text { Acute lymphoblastic } \\
\text { leukemia }\end{array}$ & $118(12.4)$ \\
\hline & Hodgkin disease & $74(7.8)$ \\
\hline & Severe aplastic anemia & $55(5.8)$ \\
\hline & Non Hodgkin lymphoma & $43(4.5)$ \\
\hline & Other & $83(8.6)$ \\
\hline \multirow[t]{6}{*}{ Conditioning } & BUCY & $363(38.1)$ \\
\hline & BUFLU & $182(19.1)$ \\
\hline & MELPHALAN & $142(14.9)$ \\
\hline & BEAM & $90(9.4)$ \\
\hline & $\mathrm{CY}+\mathrm{TBI}$ & $62(6.5)$ \\
\hline & Other & $114(12)$ \\
\hline $\begin{array}{l}\text { Pts living in } \\
\text { endemic areas of } \\
\text { any NTDs }\end{array}$ & & $953(100)$ \\
\hline
\end{tabular}

$\mathrm{RD}=$ related donor; $\mathrm{URD}=$ unrelated donor PBSC $=$ peripheral blood stem cell; $\mathrm{BM}=$ bone marrow $\mathrm{CB}=$ cord blood BUCY = busulphan + cyclophosphamide; $\mathrm{FLU}=$ fludarabine; BEAM = BCNU, Etoposide, Ara C, Melphalan; TBI = total body irradiation.

Chagas disease, malaria, leishmaniasis, dengue, yellow fever and tungiasis. Donor NTD and subsequent recipient NTD was seen in one case of leprosy and one case of tuberculosis. One patient died due to Chagas myocarditis on day +240 .

Table 3 summarizes the epidemiological risk and the main clinical characteristics of the NTDs identified. 


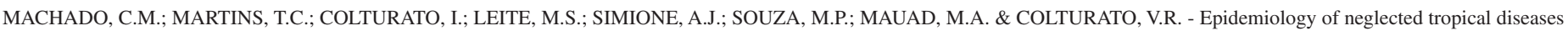
in transplant recipients. Review of the literature and experience of a Brazilian HSCT center. Rev. Inst. Med. trop. S. Paulo, 51(6): 309-324, 2009.

Table 3

Epidemiological risk and clinical characteristics of NTDs identified in HSCT donors and recipients from Amaral Carvalho Foundation.

\begin{tabular}{|c|c|c|c|c|c|c|c|c|c|c|c|}
\hline Case & Age & Gender & UD & $\begin{array}{c}\text { Person } \\
\text { affected }\end{array}$ & Time* & Management & Clinical picture & IS drugs** & GVHD* & Evolution & Follow-up \\
\hline \multicolumn{12}{|c|}{ Leprosy } \\
\hline 1 & 56 & M & CML & $\mathrm{R}$ & $4 \mathrm{yr}$ before & Observation & None & NA & NA & Death (RE) & $1 \mathrm{yr}$ \\
\hline 2 & 47 & $\mathrm{~F}$ & AML & $\mathrm{R}$ & $40 \mathrm{yr}$ before & Observation & None & NA & NA & Alive & $3 \mathrm{yr}$ \\
\hline 3 & 25 & M & SAA & $\mathrm{D}$ & $9 \mathrm{~m}$ before & Dapsone & Skin lesions & NA & NA & Alive & $2 \mathrm{yr} 6 \mathrm{~m}$ \\
\hline \multicolumn{12}{|c|}{ Tuberculosis } \\
\hline 1 & 42 & M & SAA & $\mathrm{R}$ & $20 \mathrm{yr}$ before & No prophylaxis & None & CsA & NA & Death & 370 days \\
\hline 2 & 45 & M & CML & $\mathrm{R}$ & $4 \mathrm{yr}$ before & No prophylaxis & None & NA & NA & Alive & $3 y r 6 m$ \\
\hline 3 & 27 & M & HD & $\mathrm{R}$ & $4 \mathrm{yr}$ before & No prophylaxis & None & NA & NA & Alive & $2 \mathrm{yr}$ \\
\hline 4 & 48 & $\mathrm{~F}$ & CML & $\mathrm{R}$ & $\mathrm{d}+1095$ & $1 \mathrm{yr}$ treatment & Miliary & PDN & Chronic & Alive & $1 \mathrm{yr} 5 \mathrm{~m}$ \\
\hline 5 & 12 & $\mathrm{~F}$ & ALL & $\mathrm{R}$ & $d+240$ & $6 \mathrm{~m}$ treatment & Ganglionar & CsA & Chronic & Death (TB?) & $1 \mathrm{yr} 2 \mathrm{~m}$ \\
\hline 6 & 27 & M & AML & $\mathrm{R}$ & $\mathrm{d}+45$ & $9 \mathrm{~m}$ treatment & Pleural & CsA & No & Alive & $1 \mathrm{yr} 8 \mathrm{~m}$ \\
\hline 7 & 34 & M & AML & $\mathrm{D}+\mathrm{R}$ & $d+635$ & $6 \mathrm{~m}$ treatment & Lung & CsA & No & Death (RE) & $2 \mathrm{yr} 3 \mathrm{~m}$ \\
\hline \multicolumn{12}{|c|}{ Leishmaniasis } \\
\hline 1 & 06 & M & MDS & $\mathrm{R}$ & $d+150$ & Amphotericin 21d & Kala Azar & CsA & Chronic & Death (RE) & 233 days \\
\hline \multicolumn{12}{|c|}{ Chagas disease } \\
\hline 1 & 23 & M & AML & $\mathrm{R}$ & $d+200$ & No prophylaxis & Myocarditis & CsA & Chronic & Death (CD) & 300 days \\
\hline 2 & 61 & M & MM & $\mathrm{R}$ & Before & No prophylaxis & None & NA & NA & Alive & $6 y r$ \\
\hline 3 & 54 & M & CML & $\mathrm{R}$ & Before & No prophylaxis & None & NA & NA & Alive & $4 \mathrm{yr} 7 \mathrm{~m}$ \\
\hline 4 & 45 & M & MDS & $\mathrm{R}$ & Before & No prophylaxis & None & NA & NA & Death (RE) & $1 \mathrm{yr}$ \\
\hline 5 & 53 & M & CML & $\mathrm{D}$ & Before & No prophylaxis & None & NA & NA & Alive & $5 \mathrm{yr} 2 \mathrm{~m}$ \\
\hline 6 & 37 & M & SAA & $\mathrm{R}+\mathrm{D}$ & Before & Benznidazole 22d & None & NA & No & Alive & $6 y r 2 m$ \\
\hline \multicolumn{12}{|c|}{ Malaria } \\
\hline 1 & 41 & M & ALL & $\mathrm{R}$ & Before & Observation & None & NA & NA & Alive & $1 \mathrm{yr} 7 \mathrm{~m}$ \\
\hline 2 & 26 & $\mathrm{~F}$ & ALL & $\mathrm{R}$ & Before & Observation & None & NA & NA & Death (RE) & $4 y r$ \\
\hline 3 & 33 & $\mathrm{~F}$ & ALL & $\mathrm{D}$ & Before & Observation & None & NA & NA & Alive & $2 \mathrm{yr}$ \\
\hline 4 & 31 & $\mathrm{~F}$ & SAA & $\mathrm{D}$ & Before & Observation & None & NA & NA & Death & $1 \mathrm{yr} 4 \mathrm{~m}$ \\
\hline 5 & 45 & M & CML & $\mathrm{D}$ & Before & Observation & None & NA & NA & Alive & $5 \mathrm{yr} 2 \mathrm{~m}$ \\
\hline 6 & 32 & M & AML & $\mathrm{D}$ & Before & Observation & None & NA & NA & Alive & $5 \mathrm{yr}$ \\
\hline \multicolumn{12}{|c|}{ Dengue } \\
\hline 1 & 51 & M & CML & $\mathrm{R}$ & $d+165$ & Decrease PDN & Dengue fever & CsA & Chronic & Alive & $4 \mathrm{yr}$ \\
\hline 2 & 38 & M & $\mathrm{NPH}$ & $\mathrm{R}$ & $d+575$ & Support & Dengue fever & CsA & Chronic & Alive & $2 \mathrm{yr} 6 \mathrm{~m}$ \\
\hline 3 & 39 & M & CML & $\mathrm{R}$ & $d+455$ & Support & Dengue fever & CsA & Chronic & Alive & $4 \mathrm{yr}$ \\
\hline 4 & 42 & M & AML & $\mathrm{R}$ & Before & NA & NA & NA & NA & Alive & $5 y r$ \\
\hline 5 & 45 & M & CML & $\mathrm{R}$ & Before & NA & NA & NA & NA & Alive & $6 y r$ \\
\hline 6 & 28 & M & CML & $\mathrm{D}$ & $\begin{array}{c}1 \mathrm{~m} \text { before } \\
\text { DLI }\end{array}$ & DLI delay & None & None & No & Alive & $3 \mathrm{yr}$ \\
\hline \multicolumn{12}{|c|}{ Tungiasis } \\
\hline 1 & 21 & $\mathrm{~F}$ & CML & $\mathrm{R}$ & $d+106$ & Surgery & Skin lesions & CsA & No & Alive & $3 \mathrm{yr}$ \\
\hline 2 & 22 & $\mathrm{~F}$ & MDS & $\mathrm{R}$ & d-11 & Surgery & Skin lesions & NA & NA & $\begin{array}{l}\text { Death due to } \\
\text { sepsis }\end{array}$ & $17 d$ \\
\hline
\end{tabular}

(*) in relation to HSCT; (**) at NTD diagnosis; $\mathrm{R}=$ recipient; $\mathrm{D}=$ donor; NA = not applicable; $\mathrm{Cs} \mathrm{A}=$ cyclosporine; $\mathrm{CD}=\mathrm{Chagas}$ disease; $\mathrm{RE}=$ relapse underlying disease; $\mathrm{PDN}=$ prednisone; $\mathrm{DLI}=$ donor lymphocyte infusion.

Yellow fever serology was performed in 27 recipients living in endemic areas. Information about previous vaccination was available for 24 of them. Seven patients $(29.1 \%)$ were susceptible to YF despite of pre-transplant vaccination in two of them (Table 4). Three patients were within the first two years of HSCT and were not eligible to YF vaccination. These patients were notified about their risk and instructed on precautions to avoid mosquito bites. The remaining four HSCT recipients received YF vaccine without adverse events. 


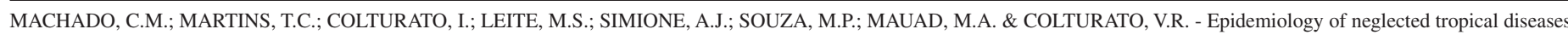
in transplant recipients. Review of the literature and experience of a Brazilian HSCT center. Rev. Inst. Med. trop. S. Paulo, 51(6): 309-324, 2009.

Table 4

Serological status of HSCT recipients according to previous history of yellow fever (YF) vaccination.

\begin{tabular}{lccc}
\hline \multirow{2}{*}{$\begin{array}{l}\text { Serological } \\
\text { status }\end{array}$} & \multicolumn{2}{c}{ Previous YF vaccinaton $(\%)$} & Total \\
\cline { 2 - 3 } & Vaccinated & Non-vaccinated & \\
\hline Susceptible & $2(28.6)$ & $5(71.4)$ & $7(100)$ \\
Immune & $14(82.3)$ & $3(17.6)$ & $17(100)$ \\
Total & $16(66.6)$ & $8(33.3)$ & $24(100)$ \\
\hline & & & $p=0.02$
\end{tabular}

\section{COMMENTS}

This retrospective study, conducted in a HSCT center receiving transplant candidates from all country regions, demonstrates that several neglected tropical diseases can affect the HSCT recipient in Brazil. The number of cases is certainly underestimated since many NTDs may have been missed because 1) unsuspected due to a benign course or 2) the epidemiological risk was not investigated in pre-transplant visits. In this series, only the blood-borne NTDs (Chagas and malaria) were investigated pre-HSCT.

A past history or contact with persons with tuberculosis is relevant information and should be actively investigated in pre-transplant visits for a better management of a suspect LTBI.

Routine tuberculin skin tests are seldom performed in Brazilian transplant centers maybe because a positive test may also reflect previous exposure to BCG vaccination or to non-tuberculous mycobacteria. Consequently, clinicians assisting those patients feel reluctant in introducing INH for nine months, despite the evidence that INH is safe and well tolerated after HSCT, even with concurrent fluconazole use ${ }^{17}$.

In our series, among the four patients who declared an epidemiological risk for $\mathrm{TB}$ (one donor with $\mathrm{TB}$, receiving treatment; three recipients with past TB), only the patient whose donor was affected developed tuberculosis, but died of disease relapse. The remaining three did not receive INH prophylaxis and did not reactivate TB. However, three other patients had tuberculosis after HSCT and their epidemiological risk was not previously investigated. These patients could have benefit from INH prophylaxis if LTBI had been actively surveyed.

A pro-active attitude to get information on epidemiological risks can also overcome social stigmas related to some diseases as in the case of leprosy. Even now, persons affected by Hansen disease frequently omit this relevant information.

Also, it is necessary to keep in mind that the HSCT recipients return to their origin place and may be re-exposed to certain agents in endemic areas. Thus, in certain regions the patient's epidemiological risk should be considered always present and taken into account not only at pretransplant visit but also during follow-up.

The Kala Azar case of this series illustrates this fact. After hospital dismissal, the children presented fever and spleen enlargement on day +150 , not responding to antibiotics. As clinical symptoms were worsening, bone marrow biopsy samples were taken to investigate a possible relapse of underlying disease. Visceral leishmaniasis was then diagnosed by the detection of leishmania amastigotes in marrow samples. Since the transplant was uneventful and retrospective review of previous bone marrow aspirates did not show leishmania, it is possible that the patient has acquired the disease after returning to his home in Bauru, an endemic area for Kala Azar in the state of São Paulo.

Concerning to Chagas disease, our data suggest that if the recipient is affected before the transplant, a high index of suspicion should be kept during whole follow-up. Reactivation can occur in the late phase of HSCT and prolonged parasitemia surveillance is not always feasible, as the patients return to their origin place. Benznidazole prophylaxis or parasitemia surveillance followed by pre-emptive introduction of benznidazole has been recommended particularly during neutropenia ${ }^{4}$.

In four patients with serological evidence of $T$. cruzi infection before HSCT, one (25\%) developed Chagas myocarditis on $\mathrm{d}+200$ and died as a consequence of the disease despite treatment. Benznidazole for 22 days was used in another recipient with serological evidence of T. cruzi infection whose donor was also affected. The transplant was uneventful and the patient is alive after 6yr of follow-up.

The management of malaria is more objective after natural exposure since the time frame for disease manifestation is shorter. Thus, parasitemia surveillance in thick blood or PCR may help to diagnose malaria in transplant candidates coming from endemic areas. We have recently compared both techniques to diagnose malaria in a HSCT recipient whose donor had a recent history of malaria. PCR detection preceded thick blood diagnosis by seven days ${ }^{50}$.

However, the value of the epidemiological risk investigation pretransplant should not be minimized since Plasmodium may persist for years in untreated malaria. Moreover, an expanding distribution of malaria areas has been observed in Brazil. Thus, all efforts should be made to exclude the possibility of infection.

Other NTDs have appeared in places where the diseases had never been diagnosed before. Dengue and yellow fever incidences have grown as a consequence of the expanding distribution of the mosquito vector.

In the present series, dengue fever had a benign course in our patients. Only support therapy was done and in one case, corticosteroid doses were diminished. In renal transplant recipients similar results have been observed in 27 dengue cases recently published ${ }^{8}$. However, we believe that dengue cases were largely underestimated because the disease can be mild or asymptomatic or, oppositely, mimic other serious complications commonly seen after HSCT such as septic shock and thrombocytopenia.

In relation to yellow fever, the main concern is the obvious risk of YF in susceptible patients living in endemic areas. Fortunately, almost 70\% of the patients tested in the present series had been previously vaccinated and $87.5 \%$ had protective antibody levels (Table 4 ). Interestingly, among the unvaccinated patients $37.5 \%$ were considered immune. The presence of YF antibodies after HSCT may reflect passive immunity from the donor or recipient exposure to yellow fever virus. Asymptomatic or mild cases of YF are common in immunocompetent hosts and may possibly also occur in HSCT recipients. 
MACHADO, C.M.; MARTINS, T.C.; COLTURATO, I.; LEITE, M.S.; SIMIONE, A.J.; SOUZA, M.P.; MAUAD, M.A. \& COLTURATO, V.R. - Epidemiology of neglected tropical diseases in transplant recipients. Review of the literature and experience of a Brazilian HSCT center. Rev. Inst. Med. trop. S. Paulo, 51(6): 309-324, 2009.

In conclusion, only prospective studies will better determine the real incidence, morbidity and mortality rates of NTDs in transplant recipients.

We are living in an increasingly globalized world in which transmission of infectious diseases has no boundaries. Tourism travels, international commerce and immigration have act as important factors for the emergence and re-emergence of specific infectious diseases.

There were an estimated 191 million migrants worldwide in 2005, comprising $3 \%$ of the global population. United States was the country hosting the greatest number of migrants ( 38.4 millions) and the top three migrant sending countries were China (35 millions), India (20 millions) and The Philippines (seven millions). An important proportion of migrant population will naturally become part of the working force as well as part of blood bank, transplant donor or transplant recipient population in destination countries ${ }^{74}$.

Many of the pathogens that cause tropical neglected diseases can be either reactivated during immunosuppression or transmitted via graft or blood transfusions. Health care workers in the field of transplantation need to be prepared to recognize the epidemiological risks and to manage the neglected tropical diseases in transplant recipients.

\section{RESUMO}

\section{Epidemiologia das doenças tropicais negligenciadas em receptores de transplantes. Revisão da literatura e experiência de um centro brasileiro}

O sucesso crescente dos transplantes de órgãos sólidos (TOS) e de células tronco-hematopoiéticas (TCTH) e as novas drogas imunossupressoras fizeram dos transplantes a primeira opção terapêutica para muitas doenças que afetam milhares de pessoas em todo o mundo. Também os populosos países em desenvolvimento investiram no crescimento de seus programas de transplante e desde então começaram a vivenciar o impacto das doenças tropicais negligenciadas (DTNs) nestes pacientes. Revisamos os dados da literatura sobre a epidemiologia das DTNs de maior impacto clinico e social que afetam receptores de transplante de países em desenvolvimento, ou que podem representar um risco para receptores de transplante vivendo em outras regiões não afetadas por estas doenças. Tuberculose, hanseníase, doença de Chagas, malaria, leishmaniose, dengue, febre amarela e sarampo são os tópicos incluídos nesta revisão. Além disso, revisamos retrospectivamente a experiência referente ao manejo das DTNs do Serviço de Transplante de Medula Óssea da Fundação Amaral Carvalho, atualmente o maior centro de TCTH alogênico do Brasil.

\section{ACKNOWLEDGMENTS}

The authors would like to thank Dr. Marcos da Silva Freire and Anna Maria Yoshida from BioManguinhos - FIOCRUZ, Ministry of Health, who kindly performed the yellow fever serology.

\section{REFERENCES}

1. ABEL, L.; SANCHEZ, F.O.; OBERTI, J. et al. - Susceptibility to leprosy is linked to the human NRAMP1 gene. J. infect. Dis., 177: 133-145, 1998.
2. AGAMANOLIS, D.P.; TAN, J.S. \& PARKER, D.L. - Immunosuppressive measles encephalitis in a patient with a renal transplant. Arch. Neurol., 36: 686-690, 1979.

3. AGUADO, J.M.; HERRERO, J.A.; GAVALDA, J. et al. - Clinical presentation and outcome of tuberculosis in kidney, liver, and heart transplant recipients in Spain. Spanish Transplantation Infection Study Group, GESITRA. Transplantation, 63 1278-1286, 1997

4. ALTCLAS, J.D.; BARCAN, L.; NAGEL, C.; LATTES, R. \& RIARTE A. - Organ transplantation and Chagas disease. J. Amer. med. Ass., 299: 1134-1135, 2008

5. ANTINORI, S.; CASCIO, A.; PARRAVICINI, C.; BIANCHI, R. \& CORBELLINO, M. - Leishmaniasis among organ transplant recipients. Lancet infect. Dis., 8: 191$199,2008$.

6. ANTINORI, S.; GIANELLI, E.; CALATTINI, S. et al. - Cutaneous leishmaniasis: an increasing threat for travellers. Clin. Microbiol. Infect., 11: 343-346, 2005.

7. AREGAWI, M.; CIBULSKIS, R.; OTTEN, M.; WILLIANS, R. \& DYE, C. - The world malaria report - 2008. WHO Global Malaria Programme, 2008. [cited 2008, Dec. 11]. www.who.int.malaria/wmr2008/malaria2008.pdf

8. AZEVEDO, L.S.; CARVALHO, D.B.; MATUCK, T. et al. - Dengue in renal transplant patients: a retrospective analysis. Transplantation, 84: 792-794, 2007.

9. BARRETT, A.D. \& HIGGS, S. - Yellow fever: a disease that has yet to be conquered. Ann. Rev. Entomol., 52: 209-229, 2007.

10. BEATTY, M.E. \& CLARK, G.G. - Dengue fever. CDC Health information for international travelers. Yellow Book 2008. [cited 2008, Dec. 11]. http://wwwn. cdc.gov/travel/yellowBookCh4-DengueFever.aspx

11. BERN, C.; MONTGOMERY, S.P.; HERWALDT, B.L. et al. - Evaluation and treatment of Chagas disease in the United States: a systematic review. J. Amer. med. Ass., 298: 2171-2181, 2007.

12. BERN, C.; MONTGOMERY, S.P.; KATZ, L.; CAGLIOTI, S. \& STRAMER, S.L. Chagas disease and the US blood supply. Curr. Opin. infect. Dis., 21: 476-482, 2008 .

13. BLOOD DONOR screening for Chagas disease. United States, 2006-2007. MMWR, 56(7): 141-143, 2007

14. BOCCHI, E.A. \& FIORELLI, A. - The paradox of survival results after heart transplantation for cardiomyopathy caused by Trypanosoma cruzi. First Guidelines Group for Heart Transplantation of the Brazilian Society of Cardiology. Ann. thorac. Surg., 71: 1833-1838, 2001

15. BOGGILD, A.K.; KEYSTONE, J.S. \& KAIN, K.C. - Leprosy: a primer for Canadian physicians. CMAJ, 170: 71-78, 2004

16. BRITTON, W.J. \& LOCKWOOD, D.N. - Leprosy. Lancet, 363(9416): 1209-1219, 2004 .

17. BUDAK-ALPDOGAN, T.; TANGUN, Y.; KALAYOGLU-BESISIK, S. et al. - The frequency of tuberculosis in adult allogeneic stem cell transplant recipients in Turkey. Biol. Blood Marrow Transplant., 6: 370-374, 2000.

18. CAMPOS, S.V.; STRABELLI, T.M.; AMATO NETO, V. et al. - Risk factors for Chagas' disease reactivation after heart transplantation. J. Heart Lung Transplant., 27 597-602, 2008.

19. CANTAROVICH, F.; VAZQUEZ, M.; GARCIA, W.D. et al. - Special infections in organ transplantation in South America. Transplant. Proc., 24: 1902-1908, 1992.

20. CETRON, M.S.; MARFIN, A.A.; JULIAN, K.G. et al. - Yellow fever vaccine Recommendations of the Advisory Committee on Immunization Practices (ACIP) 2002. MMWR Recomm. Rep., 51(RR-17): 1-11, 2002. 
MACHADO, C.M.; MARTINS, T.C.; COLTURATO, I.; LEITE, M.S.; SIMIONE, A.J.; SOUZA, M.P.; MAUAD, M.A. \& COLTURATO, V.R. - Epidemiology of neglected tropical diseases in transplant recipients. Review of the literature and experience of a Brazilian HSCT center. Rev. Inst. Med. trop. S. Paulo, 51(6): 309-324, 2009.

21. CHACKO, B.; JOHN, G.T.; JACOB, C.K. \& VIJAYAKUMAR, T.S. - Dengue shock syndrome in a renal transplant recipient. Transplantation, 77: 634-635, 2004.

22. CHAGAS DISEASE after organ transplantation. Los Angeles, California, 2006. MMWR, 55(29):798-800, 2006.

23. CHICHE, L.; LESAGE, A.; DUHAMEL, C. et al. - Posttransplant malaria: first case of transmission of Plasmodium falciparum from a white multiorgan donor to four recipients. Transplantation, 75: 166-168, 2003.

24. CHOCAIR, P.R.; SABBAGA, E.; AMATO NETO, V.; SHIROMA, M. \& DE GOES, G.M. - Transplante de rim: nova modalidade de transmissão da doença de Chagas. Rev. Inst. Med. trop. S. Paulo, 23: 280-282, 1981.

25. CIFRAS, I.N.E. - Extranjeros en España. Boletín Informativo del Instituto Nacional de Estadística, 2008 January 3. http://www.ine.es/revistas/cifraine/cifine_ext0605.pdf

26. CLARK, B.M.; MURRAY, C.K.; HORVATH, L.L. et al. - Case-control study of armadillo contact and Hansen's disease. Amer. J. trop. Med. Hyg., 78: 962-967, 2008.

27. CORDONNIER, C.; MARTINO, R.; TRABASSO, P. et al. - Mycobacterial infection: a difficult and late diagnosis in stem cell transplant recipients. Clin. infect. Dis., 38: 1229-1236, 2004.

28. CRUZ, I.; MORALES, M.A.; NOGUER, I.; RODRIGUEZ, A. \& ALVAR, J. - Leishmania in discarded syringes from intravenous drug users. Lancet, 359(9312): 1124-1125, 2002.

29. D’AlbuQUerQUe, L.A.; GONZALEZ, A.M.; FILHO, H.L. et al. - Liver transplantation from deceased donors serologically positive for Chagas disease. Amer. J. Transplant., 7: 680-684, 2007.

30. DATE, A.; JOHN, G.T.; THOMAS, P.P. \& JACOB, C.K. - Leprosy and renal transplantation. Lepr. Rev., 69: 40-45, 1998.

31. DEPARTAMENTO DE EPIDEMIOLOGÍA - Situación epidemiológica de dengue en Isla de Pascua. Ministerio de Salud de Chile, 2008. [cited 2008, Dec. 11]. http:// epi.minsal.cl/epi/html/bolets/reportes/Dengue/Informedengue.pdf

32. DEPS, P.D.; ALVES, B.L.; GRIPP, C.G. et al. - Contact with armadillos increases the risk of leprosy in Brazil: a case control study. Indian J. Derm. Venereol. Leprol., 74: $338-342,2008$

33. DESJEUX, P. - Leishmaniasis: current situation and new perspectives. Comp. Immunol. Microbiol. infect. Dis., 27: 305-318, 2004.

34. DESJEUX, P. - The increase in risk factors for leishmaniasis worldwide. Trans. roy. Soc. trop. Med. Hyg., 95: 239-243, 2001.

35. DIAS, J.P.; BASTOS, C.; ARAUJO, E. et al. - Acute Chagas disease outbreak associated with oral transmission. Rev. Soc. bras. Med. trop., 41: 296-300, 2008.

36. DUCHINI, A.; GOSS, J.A.; KARPEN, S. \& POCKROS, P.J. - Vaccinations for adult solid-organ transplant recipients: current recommendations and protocols. Clin. Microbiol. Rev., 16: 357-364, 2003.

37. EUROSURVEILLANCE EDITORIAL TEAM - Measles once again endemic in the United Kingdom. Eurosurveillance, 13(7-9), 2008. http://www.eurosurveillance. org/images/dynamic/EE/V13N27/art18919.pdf

38. FIGUEIREDO, L.T.; CAVALCANTE, S.M. \& SIMOES, M.C. - Dengue serologic survey of schoolchildren in Rio de Janeiro, Brazil, in 1986 and 1987. Bull. Pan. Amer. HIth Org., 24: 217-225, 1990.

39. FISCHER, L.; STERNECK, M.; CLAUS, M. et al. - Transmission of malaria tertiana by multi-organ donation. Clin. Transplant., 13: 491-495, 1999.

40. FREEDMAN, D.O.; WELD, L.H.; KOZARSKY, P.E. et al. - Spectrum of disease and relation to place of exposure among ill returned travelers. New Engl. J. Med., 354: 119-130, 2006.
41. FROM THE CENTERS FOR DISEASE CONTROL AND PREVENTION - Chagas disease after organ transplantation. United States, 2001. J. Amer. med. Ass., 287: 1795-1796, 2002.

42. GARCIA, J.H.; ROCHA, T.D.; VIANA, C.F. et al. - Dengue shock syndrome in a liver transplant recipient. Transplantation, 82: 850-851, 2006.

43. GASINK, L.B.; SEYMOUR, C.; BLUMBERG, E.A.; GOLDBERG, L.R. \& FISHMAN, N.O. - An uncommon presentation of an uncommon disease: leprosy in a heart transplant recipient. J. Heart Lung Transplant., 25: 854-856, 2006.

44. GAY, N.J. - The theory of measles elimination: implications for the design of elimination strategies. J. infect. Dis., 189(suppl. 1): S27-S35, 2004.

45. GIBBONS, R.V. \& VAUGHN, D.W. - Dengue: an escalating problem. BMJ, 324(7353): 1563-1566, 2002.

46. GUZMAN, M.G. \& KOURI, G. - Dengue: an update. Lancet infect. Dis., 2: 33-42, 2002.

47. HALKIC, N.; KSONTINI, R.; SCHOLL, B. et al. - Recurrent cytomegalovirus disease, visceral leishmaniosis, and Legionella pneumonia after liver transplantation: a case report. Canad. J. Anaesth., 51: 84-87, 2004.

48. HOTEZ, P.J.; BOTTAZZI, M.E.; FRANCO-PAREDES, C.; AULT, S.K. \& PERIAGO, M.R. - The neglected tropical diseases of Latin America and the Caribbean: a review of disease burden and distribution and a roadmap for control and elimination. PLoS Negl. trop. Dis., 2(9): e300, 2008.

49. HOTEZ, P.J.; MOLYNEUX, D.H.; FENWICK, A. et al. - Control of neglected tropical diseases. New Engl. J. Med., 357: 1018-1027, 2007.

50. INOUE, J.; LIMA, G.F.; NASCIMENTO, M.J. et al. - Diagnóstico molecular de malária aplicado a transplante de medula óssea: monitoramento do doador e do receptor Rev. Soc. bras. Med. trop., 42(suppl. 1): 206, 2009.

51. JOHN, G.T.; SHANKAR, V.; ABRAHAM, A.M. et al - Risk factors for post-transplan tuberculosis. Kidney Int., 60: 1148-1153, 2001.

52. JOKIPII, L.; SALMELA, K.; SAHA, H. et al. - Leishmaniasis diagnosed from bronchoalveolar lavage. Scand. J. infect. Dis., 24: 677-681, 1992.

53. KALMAN, S.; BAKKALOGLU, S.A.; OZKAYA, O.; BUYAN, N. \& SOYLEMEZOGLU, O. - Measles: a rare communicable disease in a child with renal transplantation. Pediat. Transplant., 6: 432-434, 2002.

54. KANO, H.; MIZUTA, K.; SAKAKIHARA, Y. et al. - Efficacy and safety of immunization for pre- and post- liver transplant children. Transplantation, 74: 543-550, 2002.

55. KHAN, S.; ERLICHMAN, J. \& RAND, E.B. - Live virus immunization after orthotopic liver transplantation. Pediat. Transplant., 10: 78-82, 2006.

56. KLAPPER, P.E.; CLEATOR, G.M.; CLARKE, M.C. \& POSTLETHWAITE, R.J. Measles immunization. Arch. Dis. Child, 66: 369, 1991.

57. KOSEOGLU, F.; EMIROGLU, R.; KARAKAYALI, H.; BILGIN, N. \& HABERAL, M. - Prevalence of mycobacterial infection in solid organ transplant recipients. Transplant. Proc., 33(1-2): 1782-1784, 2001.

58. LAUNIUS, B.K.; BROWN, P.A.; CUSH, E. \& MANCINI, M.C. - A case study in Hansen's disease acquired after heart transplant. Crit. Care Nurs. Q., 27: 87-91, 2004.

59. LE FICHOUX, F.Y.; QUARANTA, J.F.; AUFEUVRE, J.P. et al. - Occurrence of Leishmania infantum parasitemia in asymptomatic blood donors living in an area of endemicity in southern France. J. clin. Microbiol., 37: 1953-1957, 1999.

60. LEE, D.G.; YOO, J.H.; CHOI, J.H. et al. - A fatal case of measles pneumonia complicating an adult recipient of hemopoietic stem cell transplantation during the nationwide epidemic in Korea. Int. J. infect. Dis., 10: 410-411, 2006. 
MACHADO, C.M.; MARTINS, T.C.; COLTURATO, I.; LEITE, M.S.; SIMIONE, A.J.; SOUZA, M.P.; MAUAD, M.A. \& COLTURATO, V.R. - Epidemiology of neglected tropical diseases in transplant recipients. Review of the literature and experience of a Brazilian HSCT center. Rev. Inst. Med. trop. S. Paulo, 51(6): 309-324, 2009

61. LESSA, M.M.; LESSA, H.A.; CASTRO, T.W. et al. - Mucosal leishmaniasis: epidemiological and clinical aspects. Rev. bras. Otorrinolaringol. (Engl. Ed.), 73: 843-847, 2007

62. LINNEN, J.M.; VINELLI, E.; SABINO, E.C. et al. - Dengue viremia in blood donors from Honduras, Brazil, and Australia. Transfusion, 48: 1355-1362, 2008

63. LJUNGMAN, P.; FRIDELL, E.; LONNQVIST, B. et al. - Efficacy and safety of vaccination of marrow transplant recipients with a live attenuated measles, mumps, and rubella vaccine. J. infect. Dis., 159: 610-615, 1989.

64. JUNGMAN, P. - Vaccination after hematopoietic stem cell transplantation. In: PLOTKIN, S.A.; ORENSTEIN, W.A. \& OFFIT, P.A., ed. Vaccine. 5. ed. Philadelphia, Saunders Elselvier, 2008. p. 1403-1416.

65. LOCKWOOD, D.N. \& SUNEETHA, S. - Leprosy: too complex a disease for a simple elimination paradigm. Bull. Wld Hlth Org., 83: 230-235, 2005.

66. LUTHY, K.E.; TIEDEMAN, M.E.; BECKSTRAND, R.L. \& MILLS, D.A. - Safety of live-virus vaccines for children with immune deficiency. J. Amer. Acad. Nurse Pract., 18: 494-503, 2006.

67. MACHADO, C.M.; DE SOUZA, V.A.; SUMITA, L.M. et al. - Early measles vaccination in bone marrow transplant recipients. Bone Marrow Transplant., 35: 787-791, 2005.

68. MACHADO, C.M.; GONCALVES, F.B.; PANNUTI, C.S.; DULLEY, F.L. \& DE SOUZA, V.A. - Measles in bone marrow transplant recipients during an outbreak in Sao Paulo, Brazil. Blood, 99: 83-87, 2002.

69. MALONE, N.; BALUJA, K.F.; COSTANZO, J.M. \& DAVIS, C.J. - The foreign-born population: 2000. US Census Bureau, 2003 January 12. http://www.census.gov/ prod/2003pubs/c2kbr-34.pdf

70. MARTIN-DAVILA, P.; FORTUN, J.; LOPEZ-VELEZ, R. et al. - Transmission of tropica and geographically restricted infections during solid-organ transplantation. Clin. Microbiol. Rev., 21: 60-96, 2008.

71. MEDINA-PESTANA, J.O. \& DURO-GARCIA, V. - Strategies for establishing organ transplant programs in developing countries: the Latin America and Caribbean experience. Artif. Organs, 30: 498-500, 2006.

72. MENICHETTI, F.; BINDI, M.L.; TASCINI, C. et al. - Fever, mental impairment, acute anemia, and renal failure in patient undergoing orthotopic liver transplantation: posttransplantation malaria. Liver Transpl., 12: 674-676, 2006.

73. MENZIES, D.; PAI, M. \& COMSTOCK, G. - Meta-analysis: new tests for the diagnosis of latent tuberculosis infection: areas of uncertainty and recommendations for research. Ann. intern. Med., 146: 340-354, 2007.

74. MIGRATION IN THE TWENTY-FIRST CENTURY. FACTS AND FIGURES - Global estimates and trends. International Organization for Migration, 2008. [cited 2008 Dec. 11]. http://www.iom.int/jahia/Jahia/facts-and-figures/global-estimates-andtrends

75. MINISTÉRIO DA SAÚDE DO BRASIL. CENTRO DE VIGILÂNCIA EM SAÚDE Situação da febre amarela silvestre no Brasil, 2007 e 2008. Bol. epidemiol. CVS, 2008, November 6. [cited 2008 Dec. 11]. www.portal.saude.gov.br/portal/arquivos/ pdf/boletim_svs_febre_amarela_11_06.pdf

76. MODI, K.; MANCINI, M. \& JOYCE, M.P. - Lepromatous leprosy in a heart transplant recipient. Amer. J. Transplant., 3: 1600-1603, 2003.

77. MOHAMMED, H.; LINNEN, J.M.; MUNOZ-JORDAN, J.L. et al. - Dengue virus in blood donations, Puerto Rico, 2005. Transfusion, 48: 1348-1354, 2008.

78. MONATH, T.P. \& CETRON, M.S. - Prevention of yellow fever in persons traveling to the tropics. Clin. infect. Dis., 34: 1369-1378, 2002.
79. MUNOZ, P; RODRIGUEZ, C. \& BOUZA, E. - Mycobacterium tuberculosis infection in recipients of solid organ transplants. Clin. infect. Dis., 40: 581-587, 2005.

80. O'DONNELL, J.; GOLDMAN, J.M.; WAGNER, K. et al. - Donor-derived Plasmodium vivax infection following volunteer unrelated bone marrow transplantation. Bone Marrow Transplant., 21: 313-314, 1998.

81. PAI, M.;ZWERLING, A. \& MENZIES, D. - Systematic review: T-cell-based assays for the diagnosis of latent tuberculosis infection: an update. Ann. intern. Med., 149: 177-184, 2008.

82. PARK, S.B.; RYU, S.Y.; JIN, K.B. et al. - Acute colitis associated with dengue fever in a renal transplant recipient. Transplant. Proc., 40: 2431-2432, 2008.

83. PIERONI, F.; STRACIERI, A.B.; MORAES, D.A. et al. - Six cases of leprosy associated with allogeneic hematopoietic SCT. Bone Marrow Transplant., 40: 859-863, 2007.

84. RAND, E.B.; McCARTHY, C.A. \& WHITINGTON, P.F. - Measles vaccination after orthotopic liver transplantation. J. Pediat., 123: 87-89, 1993.

85. REINHARDT, B ; JASPERT, R.; NIEDRIG, M ; KOSTNER, C. \& L'AGE-STEHR, J. Development of viremia and humoral and cellular parameters of immune activation after vaccination with yellow fever virus strain 17D: a model of human flavivirus infection. J. med. Virol., 56: 159-167, 1998.

86. RENAUD, C.J.; MANJIT, K. \& PARY, S. - Dengue has a benign presentation in renal transplant patients: a case series. Nephrology (Carlton ), 12: 305-307, 2007.

87. RIARTE, A.; LUNA, C.; SABATIELLO, R. et al. - Chagas' disease in patients with kidney transplants: 7 years of experience 1989-1996. Clin. infect. Dis., 29: 561-567, 1999.

88. RIGAU-PEREZ, J.G.; VORNDAM, A.V. \& CLARK, G.G. - The dengue and dengue hemorrhagic fever epidemic in Puerto Rico, 1994-1995. Amer. J. trop. Med. Hyg., 64: 67-74, 2001.

89. RIMA, B.K. \& DUPREX, W.P. - Morbilliviruses and human disease. J. Path., 208: 199-214, 2006

90. RIZVI, S.A.; NAQVI, S.A.; HUSSAIN, Z. et al. - Renal transplantation in developing countries. Kidney Int., 83(suppl.): S96-S100, 2003.

91. ROSE, D.N. - Benefits of screening for latent Mycobacterium tuberculosis infection. Arch. intern. Med., 160: 1513-1521, 2000.

92. SCHMUNIS, G.A. \& CRUZ, J.R. - Safety of the blood supply in Latin America. Clin. Microbiol. Rev., 18: 12-29, 2005.

93. SCHOFIELD, C.J.; JANNIN, J. \& SALVATELLA, R. - The future of Chagas disease control. Trends Parasit., 22: 583-588, 2006.

94. SECRETARIA DE VIGILÂNCIA EM SAÚDE. PROGRAMA NACIONAL DE IMUNIZAÇÕES - Manual dos Centros de Referência para Imunobiológicos Especiais 2006. Brasília, Ministério da Saúde, 2006. [cited 2008 Dec. 11]. www. sbinfecto.org.br/anexos/MS_PNI_manual\%20CRIE\%202006.pdf

95. SINGH, N. \& PATERSON, D.L. - Mycobacterium tuberculosis infection in solid-organ transplant recipients: impact and implications for management. Clin. infect. Dis. 27: 1266-1277, 1998

96. SOUSA, A.A.; LOBO, M.C.; BARBOSA, R.A. \& BELLO, V. - Chagas seropositive donors in kidney transplantation. Transplant. Proc., 36: 868-869, 2004.

97. SUNDBERG, R.; SHAPIRO, R.; DARRAS, F. et al. - A tuberculosis outbreak in a renal transplant program. Transplant. Proc., 23: 3091-3092, 1991.

98. TAN, F.L.; LOH, D.L.; PRABHAKARAN, K.; TAMBYAH, P.A. \& YAP, H.K. Dengue haemorrhagic fever after living donor renal transplantation. Nephrol. Dial. Transplant., 20: 447-448, 2005 
MACHADO, C.M.; MARTINS, T.C.; COLTURATO, I.; LEITE, M.S.; SIMIONE, A.J.; SOUZA, M.P.; MAUAD, M.A. \& COLTURATO, V.R. - Epidemiology of neglected tropical diseases in transplant recipients. Review of the literature and experience of a Brazilian HSCT center. Rev. Inst. Med. trop. S. Paulo, 51(6): 309-324, 2009.

99. TARGETED TUBERCULIN TESTING and treatment of latent tuberculosis infection. This official statement of the American Thoracic Society was adopted by the ATS Board of Directors, July 1999. This is a Joint Statement of the American Thoracic Society (ATS) and the Centers for Disease Control and Prevention (CDC). This statement was endorsed by the Council of the Infectious Diseases Society of America. (IDSA), September 1999, and the sections of this statement. Amer. J. resp. crit. Care Med., 161(4 Pt. 2): S221-S247, 2000

100. TAVIL, B.; GULHAN, B.; OZCELIK, U. et al. - Tuberculin skin test positivity in pediatric allogeneic BMT recipients and donors in Turkey. Pediat. Transplant., 11: 414-418, 2007.

101. THAMBO, S.; PASSALACQUA, W.; VAN, C.R. \& LAZCANO, F. - Enfermedad de Chagas en trasplantados renales. Rev. med. Chile, 117: 18-22, 1989.

102. TOMBLYN, M.; CHILLER, T.; EINSELE, H. et al. - Guidelines for preventing infectious complications among hematopoietic cell transplantation recipients: a global perspective. Biol. Blood Marrow Transplant., 15: 1143-1238, 2009 and Bone Marrow Transplant., 44(8): 453-455, 2009.

103. TORRES, J.R. \& CASTRO, J. - The health and economic impact of dengue in Latin America. Cad. Saude públ. (Rio de J.), 23(suppl. 1): S23-S31, 2007.

104. TRAN, V.B.; TRAN, V.B. \& LIN, K.H. - Malaria infection after allogeneic bone marrow transplantation in a child with thalassemia. Bone Marrow Transplant., 19: 12591260, 1997.

105. TURNER, A.; JEYARATNAM, D.; HAWORTH, F. et al. - Measles-associated encephalopathy in children with renal transplants. Amer. J. Transplant., 6: 1459$1465,2006$.
106. UPDATE MEASLES. United States, January-July 2008. MMWR, 57(33): 893-896, 2008.

107. VASCONCELOS, P.F. - Febre amarela. Rev. Soc. bras. Med. trop., 36: 275-293, 2003.

108. WARMINGTON, L.; LEE, B.E. \& ROBINSON, J.L. - Loss of antibodies to measles and varicella following solid organ transplantation in children. Pediat. Transplant. 9: $311-314,2005$

109. WILDER-SMITH, A. \& SCHWARTZ, E. - Dengue in travelers. New Engl. J. Med. 353: 924-932, 2005

110. WORLD HEALTH ORGANIZATION - Control of neglected tropical diseases (NTD). WHO, 2008. [cited 2008 Dec. 11]. http://www.who.int/neglected_diseases/en/

111. WORLD HEALTH ORGANIZATION - Global tuberculosis control: surveillance, planning, financing: WHO report 2008. [cited 2008 Dec. 11]. http://www.who.int tb/publications/global_report/2008/pdf/fullreport.pdf

112. WORLD HEALTH ORGANIZATION - Measles. WHO, 2007. Fact sheet no. 286. [cited 2008 Dec. 11]. www.who.int/mediacentre/factsheets/fs286/en/

113. YOO, J.H.; LEE, D.G.; CHOI, S.M. et al. - Infectious complications and outcomes after allogeneic hematopoietic stem cell transplantation in Korea. Bone Marrow Transplant., 34: 497-504, 2004.

Received: 1 July 2009

Accepted: 27 August 2009 